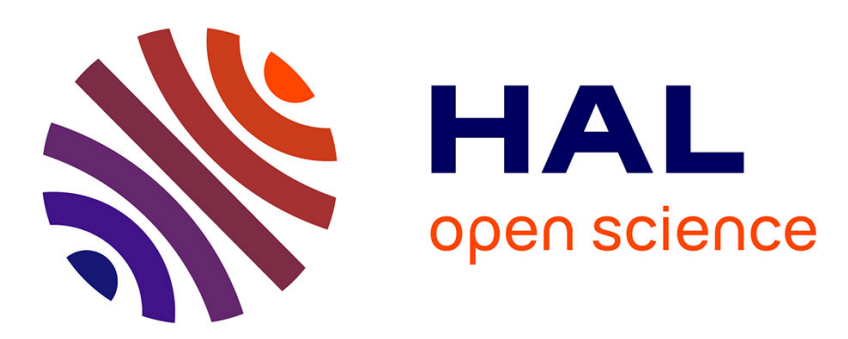

\title{
Accounting for Field-Scale Dry Deposition in Backward Lagrangian Stochastic Dispersion Modelling of NH3 Emissions
}

\author{
C. Hani, Christophe Flechard, A. Neftel, J. Sintermann, T. Kupper
}

\section{- To cite this version:}

C. Hani, Christophe Flechard, A. Neftel, J. Sintermann, T. Kupper. Accounting for Field-Scale Dry Deposition in Backward Lagrangian Stochastic Dispersion Modelling of NH3 Emissions. Atmosphere, 2018, 9 (4), pp.146. 10.3390/atmos9040146 . hal-02056884

\section{HAL Id: hal-02056884 \\ https://hal.science/hal-02056884}

Submitted on 4 Mar 2019

HAL is a multi-disciplinary open access archive for the deposit and dissemination of scientific research documents, whether they are published or not. The documents may come from teaching and research institutions in France or abroad, or from public or private research centers.
L'archive ouverte pluridisciplinaire HAL, est destinée au dépôt et à la diffusion de documents scientifiques de niveau recherche, publiés ou non, émanant des établissements d'enseignement et de recherche français ou étrangers, des laboratoires publics ou privés.

\section{(c)(1)}

Distributed under a Creative Commons Attribution| 4.0 International License 
Article

\title{
Accounting for Field-Scale Dry Deposition in Backward Lagrangian Stochastic Dispersion Modelling of $\mathrm{NH}_{3}$ Emissions
}

\author{
Christoph Häni ${ }^{1, *(D)}$, Christophe Flechard ${ }^{2}$, Albrecht Neftel ${ }^{3,+}$, Jörg Sintermann ${ }^{3, \ddagger}$ and \\ Thomas Kupper ${ }^{1}$ \\ 1 School of Agricultural, Forest and Food Sciences HAFL, Bern University of Applied Sciences, \\ 3052 Zollikofen, Switzerland; thomas.kupper@bfh.ch \\ 2 INRA, Agrocampus Ouest, UMR 1069 SAS, 35042 Rennes, France; christophe.flechard@inra.fr \\ 3 Climate and Agriculture Group, Agroscope, 8046 Zürich, Switzerland; neftel_a@bluewin.ch (A.N.); \\ sintermann@gmx.ch (J.S.) \\ * Correspondence: christoph.haeni@bfh.ch; Tel.: +41-31-910-2269 \\ + Now at: Neftel Research Expertise, 3033 Wohlen b. Bern, Switzerland. \\ $\ddagger \quad$ Now at: Office of Waste, Water, Energy and Air, Canton of Zurich, 8090 Zurich, Switzerland.
}

Received: 27 February 2018; Accepted: 4 April 2018; Published: 14 April 2018

\begin{abstract}
A controlled ammonia $\left(\mathrm{NH}_{3}\right)$ release experiment was performed at a grassland site. The aim was to quantify the effect of dry deposition between the source and the receptors $\left(\mathrm{NH}_{3}\right.$ measurement locations) on emission rate estimates by means of inverse dispersion modelling. $\mathrm{NH}_{3}$ was released for three hours at a constant rate of $Q=6.29 \mathrm{mg} \mathrm{s}^{-1}$ from a grid of 36 orifices spread over an area of $250 \mathrm{~m}^{2}$. The increase in line-integrated $\mathrm{NH}_{3}$ concentration was measured with open-path optical miniDOAS devices at different locations downwind of the artificial source. Using a backward Lagrangian stochastic (bLS) dispersion model (bLSmodelR), the fraction of the modelled release rate to the emitted $\mathrm{NH}_{3}\left(Q_{\mathrm{bLS}} / Q\right)$ was calculated from the measurements of the individual instruments. $Q_{\mathrm{bLS}} / Q$ was found to be systematically lower than 1 , on average between 0.69 and 0.91 , depending on the location of the receptor. We hypothesized that $\mathrm{NH}_{3}$ dry deposition to grass and soil surfaces was the main factor responsible for the observed depletion of $\mathrm{NH}_{3}$ between source and receptor. A dry deposition algorithm based on a deposition velocity approach was included in the bLS modelling. Model deposition velocities were evaluated from a 'big-leaf' canopy resistance analogy. Canopy resistances (generally termed $R_{c}$ ) that provided $Q_{\mathrm{bLS}} / Q=1$ ranged from 75 to $290 \mathrm{~s} \mathrm{~m}^{-1}$, showing that surface removal of $\mathrm{NH}_{3}$ by dry deposition can plausibly explain the original underestimation of $Q_{\mathrm{bLS}} / Q$. The inclusion of a dry deposition process in dispersion modelling is crucial for emission estimates, which are based on concentration measurements of depositing tracers downwind of homogeneous area sources or heterogeneously-distributed hot spots, such as, e.g., urine patches on pastures in the case of $\mathrm{NH}_{3}$.
\end{abstract}

Keywords: backward Lagrangian stochastic model; atmospheric surface-layer; micrometeorological techniques; atmospheric ammonia; dry deposition; open-path measurements; differential optical absorption spectroscopy

\section{Introduction}

Estimation of trace gas emission from confined source areas on a local scale (i.e., receptor (measurement) distance to sources less than $500 \mathrm{~m}$ ) using the combination of inverse dispersion modelling with either concentration or flux measurements is a widespread method, especially in the agricultural sector (e.g., [1-6]). 
In particular, the combination of concentration measurements with backward Lagrangian stochastic (bLS) modelling is a convenient way of emission estimation that has spurred its utilization in the past decade [7]. Flesch et al. [8] present details of a surface-layer bLS model that has been embedded in the framework of the frequently used software 'WindTrax' (http:/ / www.thunderbeachscientific. $\mathrm{com} /)$. A variety of trace gases, such as, e.g., methane $\left(\mathrm{CH}_{4}\right)$ or ammonia $\left(\mathrm{NH}_{3}\right)$, have been investigated using this model (e.g., [9-13]).

While gases like $\mathrm{CH}_{4}$ satisfy the model assumption of an inert gas, $\mathrm{NH}_{3}$ shows a high affinity to sorb on any kind of surface (e.g., $[14,15])$ and measurements of $\mathrm{NH}_{3}$ downwind of a source area will therefore be affected by the removal of $\mathrm{NH}_{3}$ through deposition between source and receptor. Thus, the concentration measurement downwind will reflect the net emission that corresponds to the $\mathrm{NH}_{3}$ exchange in the entire sector between source and receptor. If the aim is the quantification of the emission from the emitting source areas only (i.e., the gross emission flux), the deposition component must be quantified.

For short ranges, i.e., within the first few hundred meters downwind of a source area, the removal of $\mathrm{NH}_{3}$ is largely dominated by dry deposition $[16,17]$. Emission estimates without the inclusion of the dry deposition mechanism in the model run have the potential to be biased towards smaller values. The extent of this effect is poorly known and the bias due to dry deposition is usually neglected in results from field measurements.

Artificial sources can be used to validate short-range atmospheric dispersion models. Due to practical reasons, many artificial sources consist of a single or an ensemble of point releases, e.g., critical orifices. If the artificial source is located in or close to the canopy, a significant part of surface-interacting trace gases, such as $\mathrm{NH}_{3}$ is deposited within and near the source grid. This results in recovered fractions of the emitted tracer that are systematically below 1 .

In this paper, we report the extension of a bLS model to include an explicit dry deposition algorithm and we use the results from a controlled release experiment to estimate the magnitude of dry deposition between source and receptor locations. The model environment has been embedded in an R package [18] denominated bLSmodelR. The newest version of bLSmodelR is available at https://www.agrammon.ch/documents-to-download/blsmodelr/.

\section{Materials and Methods}

\subsection{Backward Lagrangian Stochastic Dispersion Model}

The employed bLS model in $b L S m o d e l R$ is a first-order Lagrangian stochastic dispersion model that is run in backward mode (i.e., backward in time) assuming horizontally homogeneous and vertically inhomogeneous, Gaussian turbulence. The vertical profiles of the wind speed and the turbulence statistics are based on Monin-Obukhov Similarity Theory (MOST).

The relation between the emission rate $(Q)$ of a homogeneous surface area and the corresponding concentration increase $(C)$ at a receptor location, is calculated as:

$$
C / Q=\frac{1}{N} \sum_{\mathrm{TD} \text { inside }}\left|\frac{2}{w_{\mathrm{TD}}}\right|,
$$

where $w_{\mathrm{TD}}$ is the vertical velocity at touchdown and $N$ is the total number of trajectories in the model run that have been released and calculated back-in-time from the receptor location. The sum consists of all touchdowns inside of the emitting area. The concentration increase $C$ represents the difference between the concentration with and without the source present. The latter is often referred to as background concentration.

All the dispersion modelling relevant equations in bLSmodelR were obtained from Flesch et al. [8]. Model aspects that are different from or not specified in Flesch et al. [8] are the following:

- For the numerical discretization, the mixed implicit-explicit Euler scheme described in Flesch et al. [19] is used. 
- The trajectories are reflected perfectly at an effective ground level, taken as the level of the roughness length $z_{0}$ above the displacement height $d$, such that the covariance of the wind components is retained.

- The initialization of the wind components at release from the receptor location is done using an orthogonal projection procedure (http:/ / stats.stackexchange.com/questions/15011/generate-arandom-variable-with-a-defined-correlation-to-an-existing-variable) that has been adapted for three correlated components. This guarantees a Gaussian distribution of initial wind components with a covariance matrix given by:

$$
\operatorname{cov}\left(\boldsymbol{U}_{\mathrm{ini}}\right)=\left(\begin{array}{ccc}
\sigma_{u}^{2} & 0 & -u_{*}^{2} \\
0 & \sigma_{v}^{2} & 0 \\
-u_{*}^{2} & 0 & \sigma_{w}^{2}
\end{array}\right)
$$

where $u_{*}$ is the friction velocity (Section 2.4.3.) and $\sigma_{u}^{2}, \sigma_{v}^{2}$, and $\sigma_{w}^{2}$ are the variances of the along-wind, the crosswind, and the vertical wind components.

- The theoretical wind profile in the model is extended by an additional term $\psi_{M}\left(\frac{z_{0}}{L}\right)$ and defined according to MOST:

$$
\bar{u}=\frac{u_{*}}{k_{v}}\left\{\ln \left(\frac{z-d}{z_{0}}\right)-\psi_{M}\left(\frac{z-d}{L}\right)+\psi_{M}\left(\frac{z_{0}}{L}\right)\right\}
$$

with the stability correction function for momentum given as:

$$
\psi_{M}(x)=\left\{\begin{array}{cc}
-4.8 x & , \text { if } L>0 \\
2 \ln \left(\frac{1+\alpha}{2}\right)+\ln \left(\frac{1+\alpha^{2}}{2}\right)-2 \operatorname{atan}(\alpha)+\frac{\pi}{2}, & \text { if } L<0
\end{array}\right.
$$

and:

$$
\alpha=(1-16 x)^{1 / 4}
$$

where $x$ is either $(z-d) / L$ or $z_{0} / L, z$ represents the geometric height (i.e., the height above ground), $L$ is the Obukhov-Length, $d$ is the displacement height, $z_{0}$ is the roughness length, $\bar{u}$ represents the temporal average of the along-wind velocity, and $k_{v}$ is the von Kármán constant (defined as 0.4).

\subsection{Dry Deposition Modelling}

\subsubsection{Basic Principle}

The deposition modelling is coupled to the dispersion modelling as a concentration modifying process that acts on each touchdown occurring outside of the predefined source areas (Figure 1).

The flux $(F)$ between the absorbing surface (at the notional height $z_{0}^{\prime}$ ) and the model effective ground level $z=d+z_{0}$, the level where touchdowns occur in the bLS model, can be approximated by the product of an exchange velocity $v_{\text {ex }}$, active through the quasi-laminar viscous sub-layer, and the difference between the concentration at the absorbing surface $C_{\left\{d+z_{0}\right\}}$ and the concentration at the model surface $C_{\left\{z_{0}^{\prime}\right\}}$ :

$$
F=v_{\mathrm{ex}}\left(C_{\left\{z_{0}^{\prime}\right\}}-C_{\left\{d+z_{0}\right\}}\right) .
$$

The super-positioning of concentrations in the bLS model (i.e., the concentration of a single trajectory can be written as the sum of concentration contributions from the background and the different sources: $C_{\text {Traj }}=C_{\mathrm{bgd}}+\sum_{i} C_{\text {Source }_{i}}$ ) allows to reformulate Equation (6) to:

$$
F=v_{\mathrm{ex}}\left(\left.C_{\left\{z_{0}^{\prime}\right\}}\right|_{\mathrm{bgd}}-\left.C_{\left\{d+z_{0}\right\}}\right|_{\mathrm{bgd}}+\left.C_{\left\{z_{0}^{\prime}\right\}}\right|_{\text {Sources }}-\left.C_{\left\{d+z_{0}\right\}}\right|_{\text {Sources }}\right)=\left.F\right|_{\text {bgd }}+\left.F\right|_{\text {Source }} \cdot
$$


With respect to the source-receptor relationship, only the flux related to the source emission is needed and the terms that are related to the background concentration are discarded without any loss of information. Further, it is assumed, that the increase in $\left.C_{\left\{z_{0}^{\prime}\right\}}\right|_{\text {Sources }}$ due to already deposited molecules from the source areas can be neglected. Thus, it holds that $\left.C_{\left\{z_{0}^{\prime}\right\}}\right|_{\text {Sources }}=0$ and Equation (7) can be written as:

$$
F=-v_{\mathrm{ex}} C_{\mathrm{TD}}
$$

where $C_{\mathrm{TD}}$ is used as synonym for $\left.C_{\left\{d+z_{0}\right\}}\right|_{\text {Sources }}$, the modelled concentration at touchdown of the trajectory. Since $C_{\mathrm{TD}}$ is strictly positive, the right-hand side of Equation (8) is always negative, i.e., a downward directional deposition flux $F_{d}$, and the exchange velocity represents in fact a surface deposition velocity $v_{d}^{*}$ :

$$
F_{d}=-v_{d}^{*} C_{\mathrm{TD}}
$$

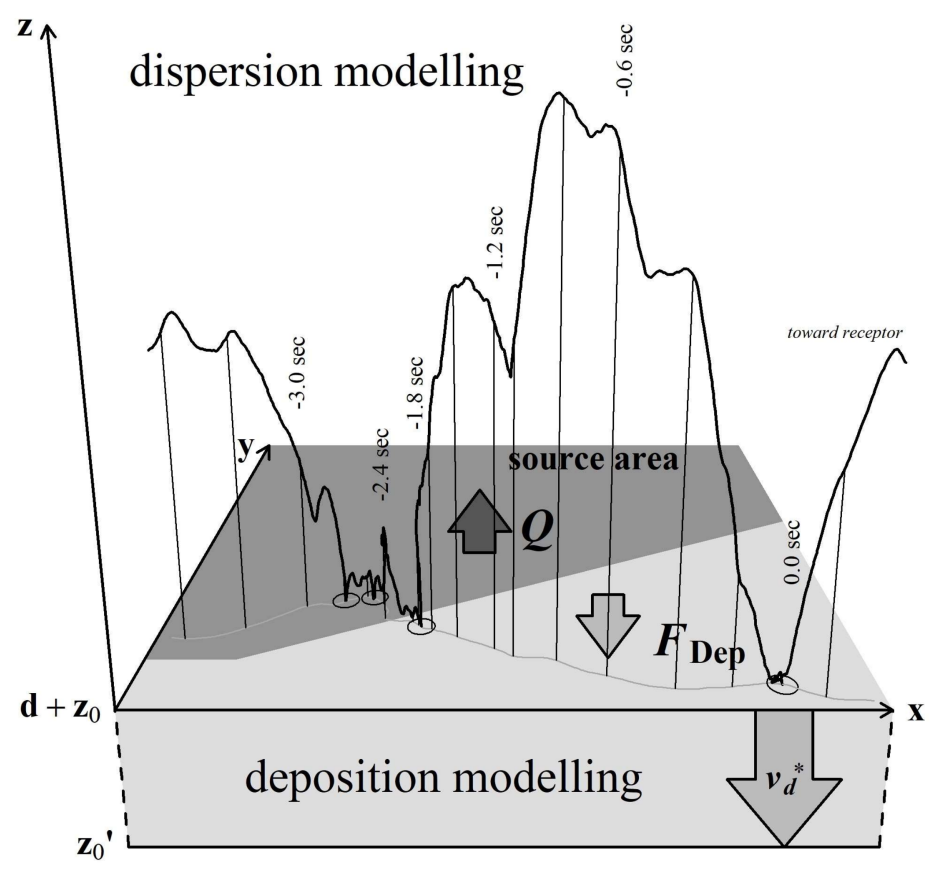

Figure 1. Illustration of the deposition modelling in the bLSmodelR. The trajectory touchdowns (indicated by circles) at $-2.5 \mathrm{~s}$ and $-2.7 \mathrm{~s}$ are inside the source area and not affected by deposition modelling; those at $-1.9 \mathrm{~s}$ and $0.0 \mathrm{~s}$ are outside the source area where deposition occurs in the model.

\subsubsection{Integration of Dry Deposition in the bLS Model}

The integration of Equation (9) into the model, whenever a touchdown occurs outside the source areas, is done by maintaining the conservation of mass for each trajectory. The change in concentration with time in a volume $V$ equals the deposition flux through the area $A$ which is orthogonal to the average flux:

$$
V \frac{d C_{\mathrm{TD}}}{d t}=A F_{d}
$$

Dividing Equation (10) by $V$ and treating volume $V$ as notional volume where the deposition takes place with an infinitesimal vertical extension $d z$ (thus, $V=A d z$ ) and further replacing $F_{d}$ by Equation (9) leads to:

$$
\frac{d C_{\mathrm{TD}}}{d t}=\frac{F_{d}}{V} A=-\frac{v_{d}^{*}}{d z} C_{\mathrm{TD}}
$$


Thus, at each touchdown, the concentration decrease can be described by integration of Equation (11) over time as:

$$
C_{>\mathrm{TD}}=C_{<\mathrm{TD}} \exp \left(-\frac{v_{d}^{*}}{d z} t_{\mathrm{TD}}\right),
$$

where $C_{>\mathrm{TD}}$ is the concentration after and $C_{<\mathrm{TD}}$ the concentration before a touchdown occurs. The 'residence time' $t_{\mathrm{TD}}$ (i.e., the amount of time that the trajectory is below $z_{0}$, in the deposition relevant volume) is given as:

$$
t_{\mathrm{TD}}=\left|\frac{2 d z}{w_{\mathrm{TD}}}\right|
$$

and thus:

$$
C_{>\mathrm{TD}}=C_{<\mathrm{TD}} \exp \left(-\left|\frac{2 v_{d}^{*}}{w_{\mathrm{TD}}}\right|\right)
$$

or equivalent, when dividing both sides by the source strength $Q$ :

$$
\{C / Q\}_{>\mathrm{TD}}=\{C / Q\}_{<\mathrm{TD}} \exp \left(-\left|\frac{2 v_{d}^{*}}{w_{\mathrm{TD}}}\right|\right) .
$$

The deposition pathway inside emitting areas is switched off, i.e., no deposition is modelled. The concentration after the touchdown occurred is only affected by the usual increase due to the source area emission, thus:

$$
\{C / Q\}_{>\mathrm{TD}}=\{C / Q\}_{<\mathrm{TD}}+\left|\frac{2}{w_{\mathrm{TD}}}\right|,
$$

if the touchdown occurs inside the source areas.

The modelled $C / Q$ ratio for a single trajectory $i$ is given as the cumulative sum over all touchdowns $j \in\{1, \ldots, M\}$, starting at the first (i.e., first in time) touchdown inside the source:

$$
\{C / Q\}_{\mathrm{dep} i}=\sum_{j=1}^{M} \begin{cases}\{C / Q\}_{\mathrm{dep} i, j-1}\left(\exp \left(-\left|\frac{2 v_{d}^{*}}{w_{\mathrm{TD}}}\right|\right)-1\right), & \text { if TD outside source } \\ \left|\frac{2}{w_{\mathrm{TD}}}\right| & , \text { if TD inside source }\end{cases}
$$

with:

$$
\{C / Q\}_{\text {dep } i, j}=\sum_{k<j}\{C / Q\}_{\text {dep }_{i, k}} .
$$

The final modelled $C$ / $Q$ ratio is given as the average value of all trajectories:

$$
\{C / Q\}_{\mathrm{dep}}=\frac{1}{N} \sum_{i=1}^{N}\{C / Q\}_{\mathrm{dep} i}
$$

The deposition algorithm described above is very similar to the deposition implementation described in Wilson et al. [20]. The two approaches differ in their derivation, but provide comparable results.

\subsection{Structure and Implementation of the bLSmodelR}

The bLS model by Flesch et al. [8] together with the deposition algorithm was implemented into an R [18] package called bLSmodelR (Supplement S1, current version available at https:/ / www. agrammon.ch/documents-to-download/blsmodelr/). The deposition algorithm was included in the bLSmodelR package as a post-processing function that allows the modelling of the dry deposition additionally to the dispersion modelling. It provides reduced $C / Q$ ratios due to the user defined dry deposition velocity, where the bLS model needs to be run first in normal mode, i.e., without the dry deposition mechanism included.

The $b L S m o d e l R$ package makes use of several different available $\mathrm{R}$ packages. A complete list of all packages that $b L S m o d e l R$ depends on can be found on the above-mentioned homepage. Amongst 
the most important ones are used mainly due to CPU time, the packages snowfall [21] and snow [22] for simple parallelization of calculation processes, Rcpp [23] for the simple implementation of the core model's C++ code (i.e., the calculation of the individual trajectories) and data.table [24] for fast calculation in the model framework.

\section{4. $\mathrm{NH}_{3}$ Release Experiment}

\subsubsection{Experimental Site}

The experiment took place on 22 September 2014 at a grassland site $\left(46^{\circ} 59^{\prime} 06^{\prime \prime} \mathrm{N} / 07^{\circ} 04^{\prime} 35^{\prime \prime} \mathrm{E}\right)$ in the Seeland region, Switzerland. The release started at $10 \mathrm{~h} 40$ local time and lasted until 13h42. The sward was treated with a broad-spectrum herbicide (glyphosate) one week before the release experiment. The height of the canopy was estimated as $9.6 \mathrm{~cm}$ on average with a rising plate pasture meter (RPM; Filip's Manual Folding Plate Meter, NZ Agriworks Ltd. t/a Jenquip, Feilding, New Zealand).

During the experiment, the wind direction varied between NE to $\mathrm{E}\left(45^{\circ}\right.$ to $\left.103^{\circ}\right)$, where the only obstacles upwind of the setup was a hedge of lower height at approx. $140 \mathrm{~m}$ and on the eastern end, a group of tall trees at approx. $200 \mathrm{~m}$ distance. The terrain was horizontally flat and homogeneous within $140 \mathrm{~m}$ upwind of the artificial source. There were two farms located within a range of $1 \mathrm{~km}$, one farm at $700 \mathrm{~m}$ distance $\mathrm{NE}\left(42^{\circ}\right)$ with pasture next to the farm buildings and another farm at a distance of $500 \mathrm{~m} \mathrm{SSE}\left(163^{\circ}\right)$.

\subsubsection{Experimental Site}

The artificial source included a gas distributor unit at the center where 12 branches consisting of polyamide tubes $(6 \mathrm{~mm}$ outer diameter $\times 4 \mathrm{~mm}$ inner diameter, Legris, Parker Hannifin, Mayfield Heights, OH, USA) were attached radially forming a hexagonal geometry (Figure 2). Each branch contained three critical flow orifices ( $100 \mu \mathrm{m}$ diameter, stainless steel, Lenox Laser Inc., Glen Arm, MD, USA) in series with $3 \mathrm{~m}$ distance between neighboring orifices. The source grid was placed at ground level and covered a notional circular area of approximately $250 \mathrm{~m}^{2}$. The gas bottle with a nominal $\mathrm{NH}_{3}$ to $\mathrm{N}_{2}$ mixing ratio of $4.97 \%$ ( $\pm 2 \%$ rel., Carbagas, Bern, Switzerland) was placed $20 \mathrm{~m}$ away from the source orifices. The constant release rate of $10 \mathrm{~L}_{\mathrm{n}} \mathrm{min}^{-1}$ was regulated and measured by a mass flow controller (red-y smart controller, Voegtlin Instruments $\mathrm{GmbH}$, Aesch, Switzerland). The $\mathrm{NH}_{3}$ total release rate of the source was given as $6.28 \mathrm{mg} \mathrm{NH}_{3} \mathrm{~s}^{-1}\left(174.6 \mu \mathrm{g} \mathrm{NH}_{3} \mathrm{~s}^{-1}\right.$ per orifice). The response time of the source, i.e., the time between the switching-on of the flow and the reaching of the total $\mathrm{NH}_{3}$ release rate at the exit (orifices), is in the order of minutes.

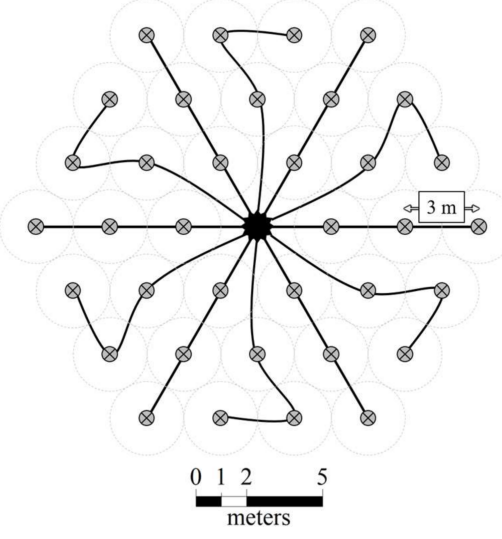

Figure 2. Schematic of the artificial source setup. Black/grey circles with crosses: orifices; black lines: polyamide tubes. 


\subsubsection{Dispersion Model Input}

The high-frequency fluctuations of 3D wind components along with the sonic temperature were measured at $10 \mathrm{~Hz}$ using an ultrasonic anemometer (WindMaster ${ }^{\mathrm{TM}}$ Pro, Gill Instruments Limited, Lymington, UK). Since the raw data of the WindMaster ${ }^{\mathrm{TM}}$ Pro series includes a bug produced by the firmware they were corrected according to the indications communicated by Gill instruments (http://gillinstruments.com/data/manuals/KN1509_WindMaster_WBug_info.pdf). The ultrasonic anemometer (denominated 'Sonic') was placed next to the $\mathrm{NH}_{3}$ measurements at a height of $1.25 \mathrm{~m}$ above ground level (a.g.l.) and oriented towards magnetic north using a geological compass. The orientation of the Sonic was corrected by the magnetic declination, i.e., the deviation of the magnetic north to the geographic north. A bubble level was used to align the Sonic in the vertical axis.

The raw data from the Sonic was averaged on a 10-min basis. The wind vector was rotated twice to provide a wind vector with components $u, v$, and $w$, representing the along-wind, crosswind and vertical velocity, respectively. The first rotation in the horizontal adjusted the $\mathrm{x}$-axis to the 10-min mean wind direction and the second rotation was done afterwards around the new y-axis until the mean vertical wind equaled zero. All sonic data were linearly detrended and the required model input parameters were calculated from these processed data.

The following set of input parameters must be specified in bLSmodelR: the three MOST parameters $\left\{u_{*}, L, z_{0}\right\}$, the wind statistics $\left\{\sigma_{u}, \sigma_{v}, \sigma_{w}\left(z_{\sigma w}\right)\right\}$ with corresponding height $z_{\sigma w}$ where the standard deviation of the vertical wind component was estimated, the displacement height $d$ and the wind direction $\beta$.

Specifically, the friction velocity was calculated as:

$$
u_{*}=\sqrt{-\overline{u / w 1}}
$$

where the overbar represents the temporal average of the product of and the prime denotes the deviation from the average of the rotated wind components $u$ and $w$, respectively. The displacement height was taken to be $2 / 3$ of the canopy height, resulting in $d=6.4 \mathrm{~cm}$. The value of the roughness length $\left(z_{0}\right)$ was estimated in an iterative procedure solving Equation (3) for $z_{0}$ by providing $\bar{u}, u_{*}$ and $L$ from sonic anemometer measurements.

The bLS model was run by supplying direct measurements of the wind statistics $\sigma_{u}, \sigma_{v}, \sigma_{w}$ implying a varying Kolmogorov coefficient $\left(C_{0}\right)$ and related to that, a varying eddy diffusivity equivalent of the model.

\subsubsection{Concentration Measurement}

The $\mathrm{NH}_{3}$ concentrations in the ambient air were determined with miniDOAS instruments described in detail by Sintermann et al. [25]. They are open-path (thus, sample inlet-free) optical devices that measure the concentration of $\mathrm{NH}_{3}$, sulfur dioxide $\left(\mathrm{SO}_{2}\right)$ and nitric oxide $(\mathrm{NO})$ as line-integrated averages over a measurement path between a light source and a detector (spectrometer) by UV absorption in the wavelength range of 200 to $230 \mathrm{~nm}$. The light path is returned by a retroreflector typically at 10 to $50 \mathrm{~m}$ from the light source to keep the light source and the detector at the same location in an actively ventilated, temperature stabilized box (Figure 3).

The four miniDOAS were placed $15 \mathrm{~m}$ downwind of the source center at three heights (locations denominated near / bottom at $0.5 \mathrm{~m}$, near /middle at $1.25 \mathrm{~m}$ and near $/$ top at $3.0 \mathrm{~m}$ ) and $70 \mathrm{~m}$ downwind of the source center at a height of $1.2 \mathrm{~m}$ (location denominated far) (Figure 4). The measurement paths were approx. $70 \mathrm{~m}$ (i.e., distance between box and reflector $\approx 35 \mathrm{~m}$ ) for all miniDOAS instruments.

The positions of all instruments and the individual orifices were recorded by a Global Positioning System (approx. precision $10 \mathrm{~cm}$, GPS Trimble R8 GNSS, Sunnyvale, CA, USA). 


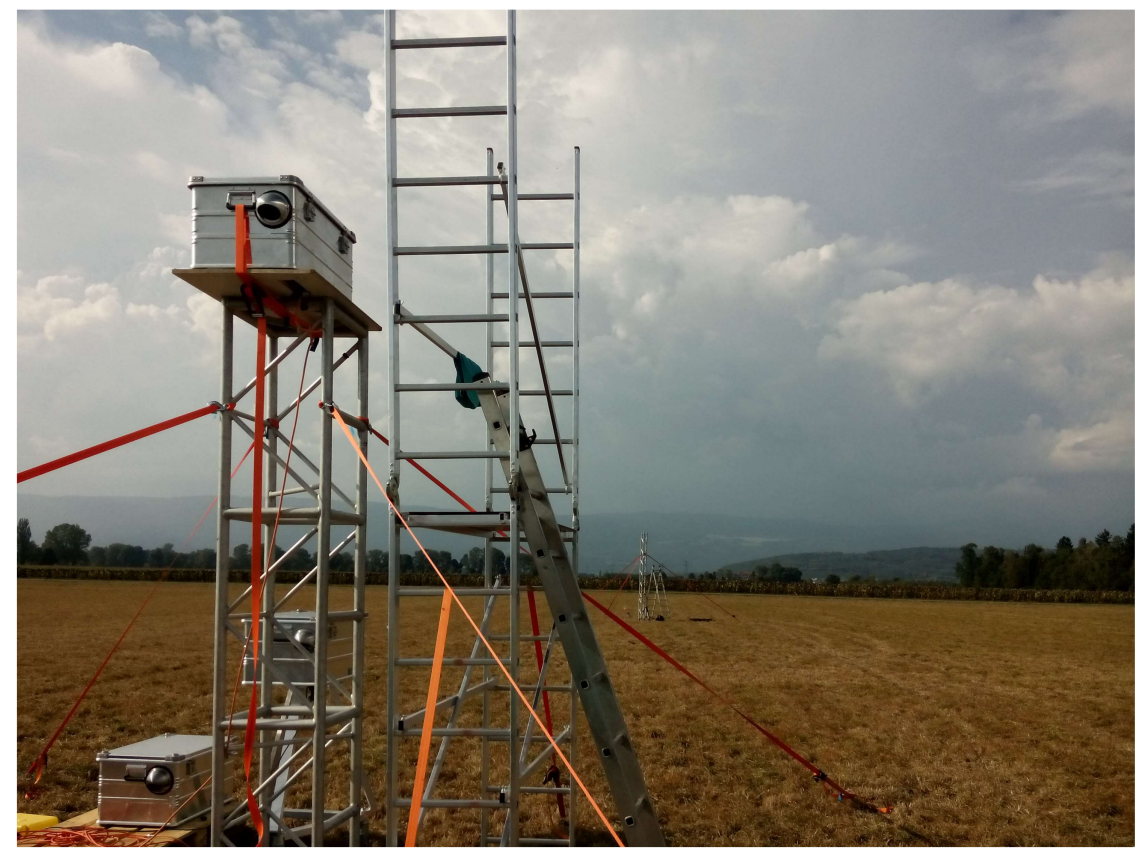

Figure 3. Three miniDOAS instruments located at the release site, $15 \mathrm{~m}$ downwind of the source center (position near). The distances between the boxes containing the light source and the detector (picture foreground) and the reflectors (picture background) were approx. $35 \mathrm{~m}$. The measurement heights were $0.5 \mathrm{~m}$ (near/bottom), $1.25 \mathrm{~m}$ (near/middle), and $3.0 \mathrm{~m}$ (near/top) above ground.

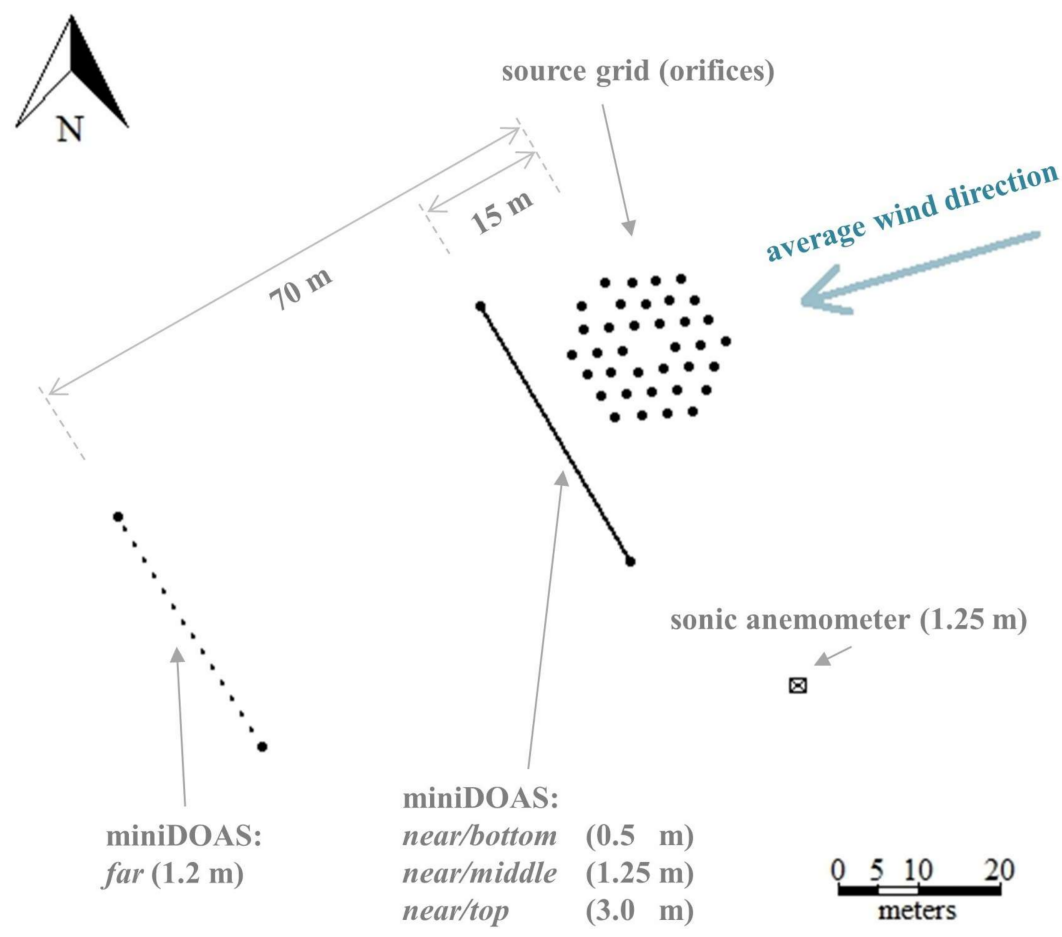

Figure 4. Position of the source (orifices) and the instruments during the artificial source release experiment as measured with the GPS device. Three miniDOAS (near/top, near/middle, and near/bottom) were located close to the artificial source at three different heights, one miniDOAS was located further downwind (far). The average wind direction during the release experiment is indicated by the blue arrow. 


\subsubsection{Background Concentration}

The background concentration for each individual miniDOAS instrument was linearly interpolated from the concentration measurement before and after the release. The concentration measurements during daytime several days before and after the release experiment with wind from the northeasterly sector (the prevailing wind direction during the release experiment) showed little variation over time and a linear interpolation of the background concentration seems appropriate for the short time of the release. The measured background concentration immediately before and after the release was around $4 \mu \mathrm{g} \mathrm{m}^{-3}$.

\subsubsection{Recovered Fraction of the Tracer Gas}

The ratio of the modelled to the emitted release rate (i.e., the recovered fraction of $\mathrm{NH}_{3}$ by the model) was calculated as:

$$
Q_{\mathrm{bLS}} / Q=\frac{C_{m}-C_{b}}{Q_{\mathrm{src}}\left\{\frac{C}{Q}\right\}_{\text {sim }}},
$$

where $C_{b}$ is the contribution of the background concentration to the measured total concentration $C_{m}$, both in $\mu \mathrm{g} \mathrm{NH}_{3} \mathrm{~m}^{-3}, Q_{\text {src }}$ is the emission rate of the source in $\mu \mathrm{g} \mathrm{NH}_{3} \mathrm{~m}^{-2} \mathrm{~s}^{-1}$ and $\left\{\frac{C}{Q}\right\}_{\text {sim }}$ is the modelled $C / Q$ ratio in $\mathrm{s} \mathrm{m}^{-1}$ calculated from Equation (1) if dry deposition was not included or Equation (19) if deposition was included in the model run. For the model calculation of $\left\{\frac{C}{Q}\right\}_{\text {sim }}$ the source area was defined as 36 circular areas of $5 \mathrm{~cm}$ radius, all emitting with equal strength of $Q_{\text {src }}=22.24 \mathrm{mg} \mathrm{NH}_{3} \mathrm{~m}^{-2} \mathrm{~s}^{-1}$.

\subsubsection{Surface Deposition Velocity}

For each estimate of the recovery rate $Q_{\mathrm{bLS}} / Q$ (i.e., each interval at each location), the near-surface deposition velocity $\left(v_{d}^{*}\right)$ (Section 2.2) was evaluated by running the model deposition post-processing with different values of $v_{d}^{*}$ and its optimum was estimated from these results. The values of $v_{d}^{*}$ that were provided as input to the bLS dry deposition modelling were approximated by a resistances approach [26], where $v_{d}^{*}$ is modelled as the inverse of the sum of a series of different resistances to deposition:

$$
v_{d}^{*}=\frac{1}{R_{b}+R_{c}} .
$$

$R_{b}$ and $R_{c}$ represent transfer resistances below the aerodynamic surface $\left(d+z_{0}\right)$, with $R_{b}$ the pseudo-laminar boundary layer resistance and $R_{c}$ a bulk (big-leaf) canopy resistance, respectively. The aerodynamic resistance $\left(R_{a}\right)$ usually included in resistance schemes is not included in Equation (22), since $v_{d}^{*}$ is defined between $d+z_{0}$ and the absorbing surface $\left(z_{0}^{\prime}\right)$, and, therefore, $R_{a}$ is already implicitly accounted for in bLS dispersion modelling.

The pseudo-laminar resistance $R_{b}$ was calculated following Garland [27] as:

$$
R_{b}=\frac{1.45\left(\frac{z_{0} u_{*}}{v}\right)^{0.24}\left(\frac{v}{D}\right)^{0.8}}{u_{*}},
$$

where $z_{0}$ is the roughness length, $u_{*}$ the friction velocity, $v$ the kinematic viscosity of air and $D$ the molecular diffusivity of $\mathrm{NH}_{3}$ in air. The temperature and pressure dependence of the diffusion coefficient was approximated according to the Chapman-Enskog theory of gas diffusion [28]:

$$
D=D_{0} \frac{p_{0}}{p}\left(\frac{T}{T_{0}}\right)^{3 / 2},
$$


where $p$ is the actual air pressure and $T$ is the actual air temperature. The standard diffusion coefficient of ammonia in air $\left(D_{0}=0.20487 \mathrm{~cm}^{2} \mathrm{~s}^{-1}\right.$ at $p_{0}=1 \mathrm{~atm}$ and $\left.T_{0}=273 \mathrm{~K}\right)$ is calculated as the average of the values summarized in Tang et al. [29].

To estimate the effective magnitude of $v_{d}^{*}$, based on the assumption that dry deposition was the main reason for the observed incomplete recovery rates, $R_{c}$. was varied from 0 to $500 \mathrm{~s} \mathrm{~m}^{-1}$ in steps of $50 \mathrm{~s} \mathrm{~m}^{-1}$. In a first step, the optimum of $R_{c}$ (henceforth referred to as $R_{c}^{1}$ ) was estimated with local polynomial regression ( $R$ function loess) from the post-processed results such that $Q_{\mathrm{bLS}} / Q=1$. This yields a 'best estimate' of $R_{c}$ anywhere in the range between 0 and $\infty \mathrm{s} \mathrm{m}^{-1}$. In a second step, the corresponding optimum of $v_{d}^{*}$ was calculated from Equation (22).

The reason for the indirect analysis of $v_{d}^{*}$ via $R_{c}$ is given in $R_{c}$ being a surface property that is expected to change only marginally during the release experiment in contrast to the turbulence affected $v_{d}^{*}$. Furthermore, $R_{c}$ can, in theory, be approximated based on certain environmental parameters like air temperature, relative humidity and $\mathrm{SO}_{2}$ concentration as discussed in Section 4.2.

\section{Results}

\subsection{Environmental Data}

\subsubsection{Meteorological Conditions and Dispersion Parameters}

On the day of the experiment, the weather was sunny with a steady easterly wind. During the release, the air temperature increased from 15.5 to $18.9^{\circ} \mathrm{C}$ with an average of $17.6^{\circ} \mathrm{C}$, whereas the relative humidity dropped from $61 \%$ to $43 \%$ (average: $51 \%$ ) (Figure $5 \mathrm{e}$ ). The 10 -min averaged wind speed at 1.25 meters above ground level from the sonic anemometer measurements ranged from 1.7 to $2.7 \mathrm{~m} \mathrm{~s}^{-1}$ (average: $2.2 \mathrm{~m} \mathrm{~s}^{-1}$ ) with wind directions ranging between $45^{\circ}$ and $103^{\circ}$ with an average of $74^{\circ}$ (Figure 5c).

The friction velocity $u_{*}$ ranged between 0.16 and $0.26 \mathrm{~m} \mathrm{~s}^{-1}$. The Obukhov length $L$ ranged from -1.3 to $-7.1 \mathrm{~m}$ (Figure $5 \mathrm{~d}$ ). The roughness length $z_{0}$ estimated from Equation (3) averaged to $1.0 \mathrm{~cm}$ (range: 0.2 to $2.4 \mathrm{~cm}$ ). The scaled standard deviations for the three components of wind ranged from 3.1 to 4.8 (average: 4.0 ) for $\sigma_{u} / u_{*}, 3.0$ to 6.9 (average: 4.5 ) for $\sigma_{v} / u_{*}$ and 1.15 to 1.90 (average: 1.47) for $\sigma_{w} / u_{*}$, resulting in a range of $b_{w}\left(\sigma_{w} / u_{*}\right.$ at ground level) from 0.99 to 1.35 (average: 1.16$)$ or a corresponding Kolmogorov coefficient $C_{0}$ of the bLS model between 3.2 and 5.1 (average: 3.9). 

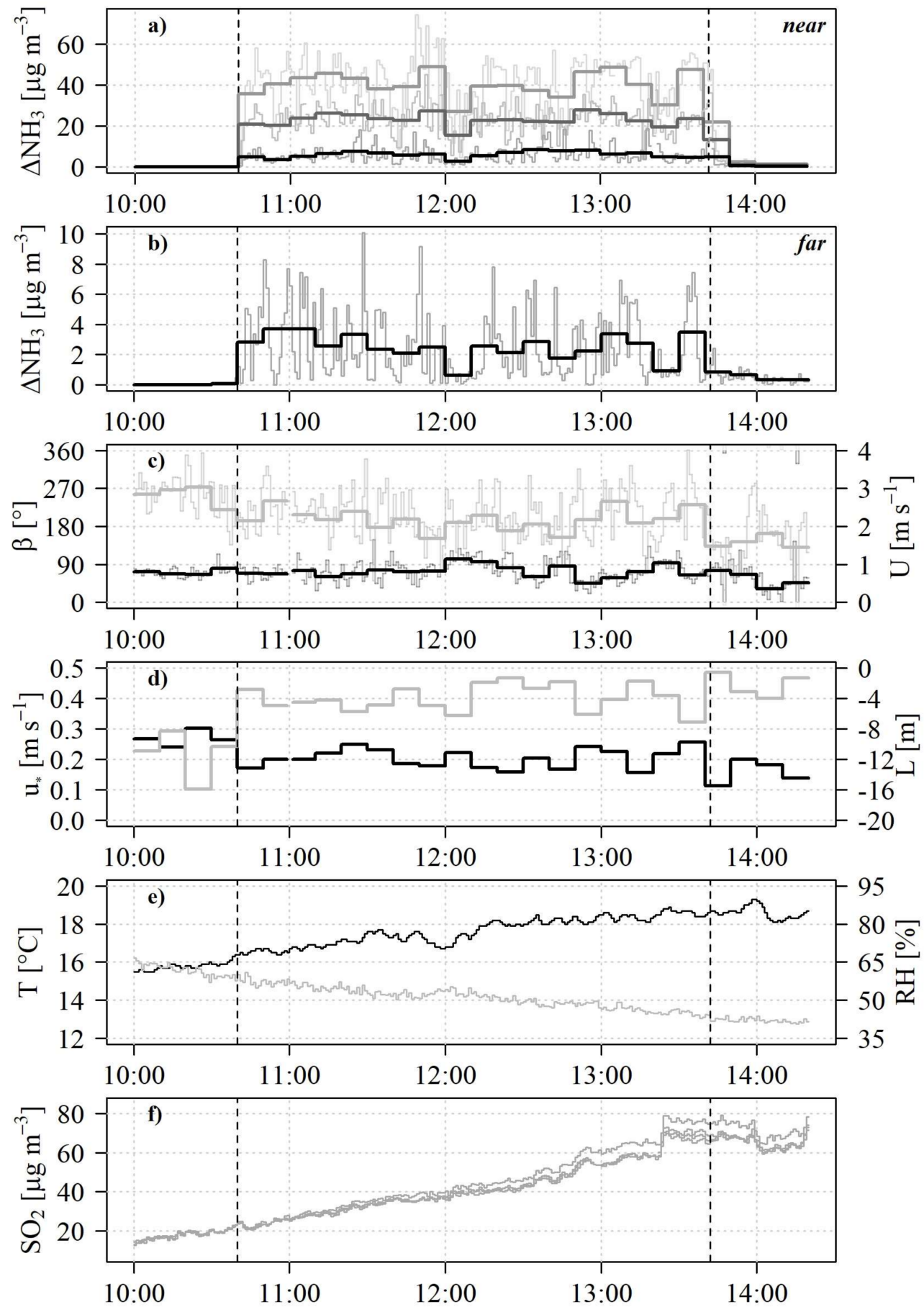

Figure 5. Overview on the measured variables during the release experiment. Thin/thick lines show the 1-/10-min averages of the measurements. Black vertical dotted lines indicate the start at 10h40 and the end at $13 \mathrm{~h} 42$ (local time) of the $\mathrm{NH}_{3}$ release. Panels (top to bottom): (a) Measured $\mathrm{NH}_{3}$ concentration increase above background for the miniDOAS instruments at position near: light grey: near/bottom; grey: near/middle; black: near/top. (b) Measured $\mathrm{NH}_{3}$ concentration increase above for the miniDOAS instruments at position far. (c) Wind direction $\beta$ in ${ }^{\circ}$ from $N$ (black lines) and wind speed $U$ in $\mathrm{m} \mathrm{s}^{-1}$ (grey lines) measured with the sonic anemometer at $1.25 \mathrm{~m}$ a.g.l. (d) Friction velocity $u_{*}$ in $\mathrm{m} \mathrm{s}^{-1}$ (black line) and Obukhov Length $L$ in $\mathrm{m}$ (grey line) as calculated on a 10-min basis. (e) Air temperature $T$ in ${ }^{\circ} \mathrm{C}$ (black line) and relative humidity $R H$ in \% (grey line) measured at $1.25 \mathrm{~m}$ a.g.l. (f) Ensemble of the $\mathrm{SO}_{2}$ concentration measurements from the individual instruments. The $\mathrm{SO}_{2}$ plume from the Bárðarbunga volcano passed the experimental area during the $\mathrm{NH}_{3}$ release. 


\subsection{2. $\mathrm{SO}_{2}$ Plume}

Simultaneous to the $\mathrm{NH}_{3}$ concentration, the concentrations of $\mathrm{NO}$ and $\mathrm{SO}_{2}$ were recorded with the miniDOAS instruments. Co-deposition of $\mathrm{SO}_{2}$ is likely to influence the magnitude of dry deposition of $\mathrm{NH}_{3}$ [30]. An $\mathrm{SO}_{2}$ plume originating from the eruption of the Icelandic volcano Bárðarbunga passed the location from $08 \mathrm{~h} 00$ (local time) to $17 \mathrm{~h} 00$ [25], raising the $\mathrm{SO}_{2}$ concentration from 20 to $70 \mu \mathrm{g} \mathrm{m}^{-3}$ during the $\mathrm{NH}_{3}$ release with highest concentration just at the end of the release experiment (Figure $5 \mathrm{f}$ ). There was no detectable difference in the $\mathrm{SO}_{2}$ concentration between the three miniDOAS systems close to the $\mathrm{NH}_{3}$ source, but the instrument at position far was higher by roughly $10 \%$.

\section{2. $\mathrm{NH}_{3}$ Concentration}

The average increase in the measured $\mathrm{NH}_{3}$ concentration during the $\mathrm{NH}_{3}$ release period amounted to $39.7 \mu \mathrm{g} \mathrm{m}^{-3}$ (near/bottom), $22.6 \mu \mathrm{g} \mathrm{m}^{-3}$ (near/middle), $6.3 \mu \mathrm{g} \mathrm{m}^{-3}$ (near/top), and $2.7 \mu \mathrm{g} \mathrm{m}^{-3}$ (far) (Figure $5 \mathrm{a}, \mathrm{b}$ ). The standard deviation $\sigma_{\mathrm{NH} 3}$ of the measured concentration increased from $0.5 \mu \mathrm{g} \mathrm{m}^{-3}, 0.3 \mu \mathrm{g} \mathrm{m}^{-3}, 0.2 \mu \mathrm{g} \mathrm{m}^{-3}$, and $0.8 \mu \mathrm{g} \mathrm{m}^{-3}$ before and after the release to $11.5 \mu \mathrm{g} \mathrm{m}^{-3}$, $6.0 \mu \mathrm{g} \mathrm{m}^{-3}, 3.2 \mu \mathrm{g} \mathrm{m}^{-3}$, and $2.3 \mu \mathrm{g} \mathrm{m}^{-3}$ during the release for the near/bottom, near/middle, near/top, and far measurement location, respectively. The standard deviation of the $\mathrm{NH}_{3}$ concentration at position far during the release phase was of the same order as the average increase above background concentration. The instruments' random errors (i.e., the standard error (SE) of the coefficient estimates from the instrument's curve fitting, reflecting the quality of the measurement) averaged to $0.3 \mu \mathrm{g} \mathrm{m}^{-3}$, $0.5 \mu \mathrm{g} \mathrm{m}^{-3}, 0.3 \mu \mathrm{g} \mathrm{m}^{-3}$, and $0.6 \mu \mathrm{g} \mathrm{m}^{-3}$ during the release and changed only marginally from background concentration measurements. All instruments showed a similar temporal behavior in the measured concentration, with a residual tailing of the concentration above background after the gas flow through the source stopped, i.e., the $\mathrm{NH}_{3}$ concentration did not instantaneously drop to background levels, unlike the case for $\mathrm{CH}_{4}$ (data not shown).

\subsection{Recovered Fractions of $\mathrm{NH}_{3}$ without Deposition Modelling}

The calculated recovered fractions $Q_{\mathrm{bLS}} / Q$ from the standard model runs are shown in Figure 6. The average $Q_{\mathrm{bLS}} / Q$ was significantly below 1 for each instrument, estimated as 0.88 (near $/$ bottom), 0.91 (near/middle), 0.83 (near/top) and 0.69 (far). The corresponding standard deviations $\sigma_{Q} / Q$ were smaller in the case of larger fractions recovered, i.e., 0.11 (near/bottom, number of intervals $n=18), 0.12$ (near /middle, $\mathrm{n}=18$ ), versus 0.19 (near /top, $\mathrm{n}=18$ ) and 0.19 (far, $\mathrm{n}=17$ ). One interval (from 12h10 to $12 \mathrm{~h} 20)$ from the measurement at position far showed a very high recovery rate $\left(Q_{\mathrm{bLS}} / Q=4.4\right)$ exceeding the average $Q_{\mathrm{bLS}} / Q$ by approx. 20 times the standard deviation, indicative of large measurement or modelling errors and, thus, was excluded from the further analysis. The SE of the individual $Q_{\mathrm{bLS}} / Q$ estimates (i.e., on an interval basis) were calculated from error propagation. They were also smaller in the case of the larger recovered fractions, i.e., 0.10 (near/bottom), 0.11 (near/middle), versus 0.13 (near/top) and 0.32 (far). The error propagation assumed independent error contributions from (a) the $\mathrm{NH}_{3}$ release rate with an $\mathrm{SE}$ of the $\mathrm{NH}_{3}$ release rate assumed to be $5 \%$ of the absolute release rate, (b) the concentration measurement (individual SE given by the miniDOAS instruments), (c) the background concentration estimation (SE assumed to be $0.5 \mu \mathrm{g} \mathrm{m}^{-3}$ ), and (d) the model calculation of the $C / Q$ ratio (SE given by the stochastic error obtained from the model calculation and a systematic model error, which was assumed to be $10 \%$ of the model result). 


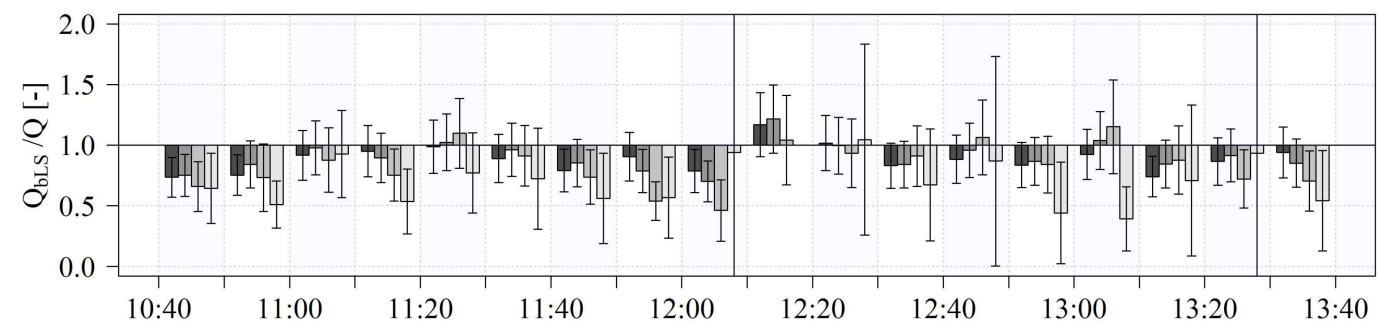

Figure 6. Calculated recovery rates $Q_{\mathrm{bLS}} / Q$ from model runs without accounting for deposition. The order of the instrument position is given (within an interval) from left (darkest grey) to right (lightest grey) as near/bottom, near/middle, near/top, and far. Vertical lines indicate the $95 \%$ confidence region of the individual estimates. One interval from the measurement at position far (12h10 to $12 \mathrm{~h} 20$, $Q_{\mathrm{bLS}} / Q=4.4$ ) was excluded from the analysis.

\subsection{Canopy Resistance and Surface Deposition Velocity}

When considering the ensemble of all intervals, the $R_{c}$ values that were required to raise the uncorrected $Q_{\mathrm{bLS}} / Q$ values closest to $1\left(R_{c}^{1}\right)$ and the corresponding average surface deposition velocities $\left(\overline{v_{d}^{*}}\right)$ were $280 \mathrm{~s} \mathrm{~m}^{-1},\left(\overline{v_{d}^{*}}=0.34 \mathrm{~cm} \mathrm{~s}^{-1}\right)$ for position near/bottom, $290 \mathrm{~s} \mathrm{~m}^{-1}$ $\left(\overline{v_{d}^{*}}=0.33 \mathrm{~cm} \mathrm{~s}^{-1}\right)$ for position near/middle, $120 \mathrm{~s} \mathrm{~m}^{-1}\left(\overline{v_{d}^{*}}=0.74 \mathrm{~cm} \mathrm{~s}^{-1}\right)$ for position near/top and $75 \mathrm{~s} \mathrm{~m}^{-1}\left(\overline{v_{d}^{*}}=1.11 \mathrm{~cm} \mathrm{~s}^{-1}\right)$ for position far. Figure 7 shows the numerical impact of the investigated range of $R_{c}$ (and $\overline{v_{d}^{*}}$ ) values on the calculated $Q_{\mathrm{bLS}} / Q$. The maximum deposition possible $\left(R_{c}=0 \mathrm{~s} \mathrm{~m}^{-1}\right)$ resulted in $Q_{\mathrm{bLS}} / Q$ averages between 1.6 and 2.0 .
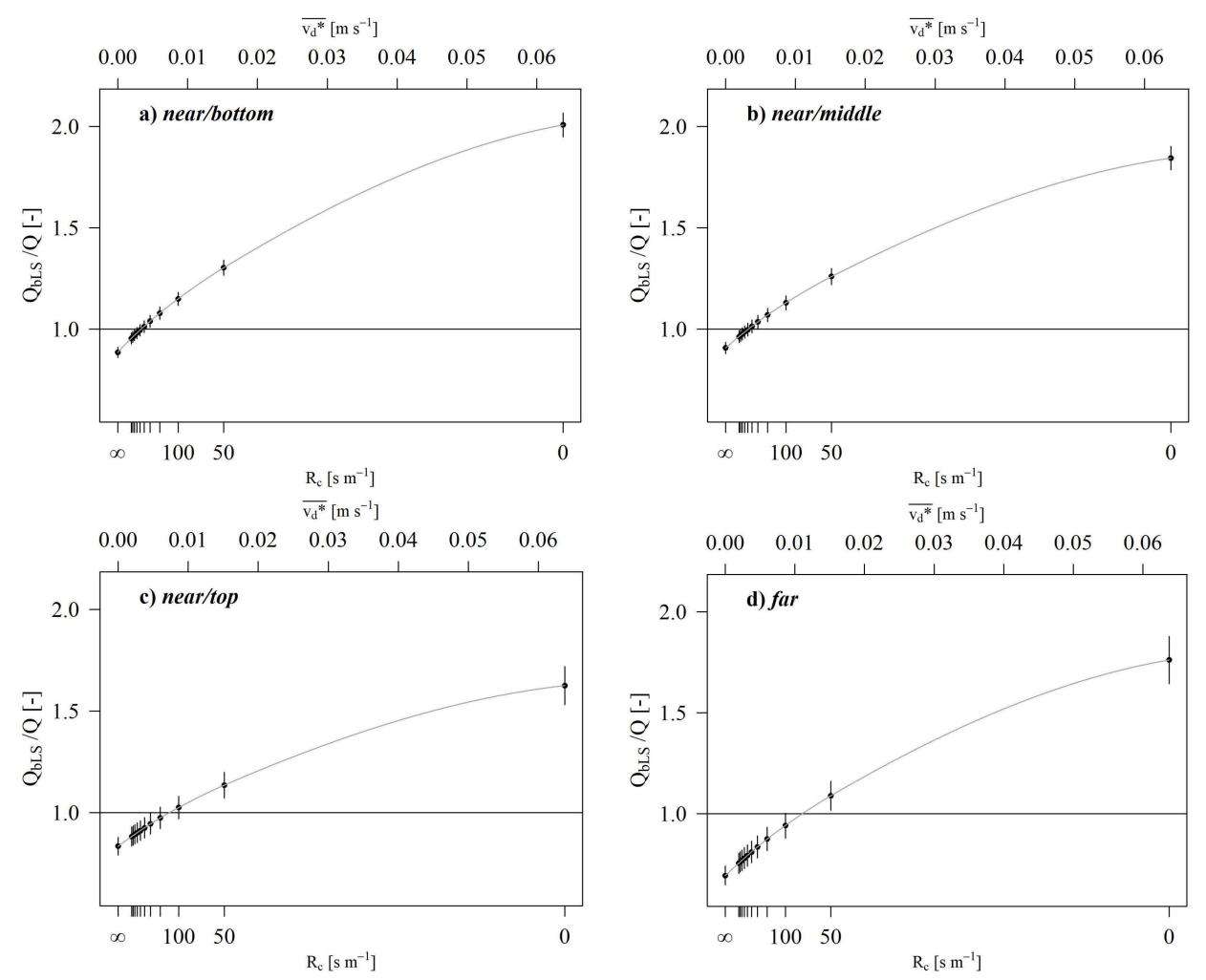

Figure 7. Sensitivity of the $Q_{\mathrm{bLS}} / Q$ ratio to the canopy resistance $R_{c}$ and the average of the corresponding surface deposition velocities $\overline{v_{d}^{*}}$ (secondary $\mathrm{x}$-axis on top). Points and vertical lines indicate the average $Q_{\mathrm{bLS}}$ / $Q$ over all intervals with the associated $95 \%$ confidence intervals. The line shows the local polynomial regression estimate. 
Regarding the results from individual intervals, the medians of $v_{d}^{*}$ were $0.28 \mathrm{~cm} \mathrm{~s}^{-1}$ (near $/$ bottom), $0.42 \mathrm{~cm} \mathrm{~s}^{-1}$ (near/middle), $0.67 \mathrm{~cm} \mathrm{~s}^{-1}$ (near/top) and $1.06 \mathrm{~cm} \mathrm{~s}^{-1}$ (far). Values of $R_{c}^{1}$ with the corresponding surface deposition velocities for each interval are given in Table A1 of the Appendix A.

\section{Discussion}

\subsection{Recovered Fraction of $\mathrm{NH}_{3}$ without Deposition Modelling}

The recovered fractions $Q_{\mathrm{bLS}} / Q$ for the standard model runs showed similar patterns with time of the release experiment at the four measurement locations (Figure 6) averaging over all intervals between 0.69 and 0.91 times the expected release rate $Q_{\text {src }}$. The variation in between different intervals was small $\left(\sigma_{Q / Q}\right.$ between 0.11 and 0.19$)$ and compared well to previously-published results (e.g., Table A1 in Harper et al., [12]).

The SE in the $Q_{\mathrm{bLS}} / Q$ estimate at position far is approx. three times higher than at positions near/bottom, near/middle, and near/top. The following factors explain the larger uncertainty at position far compared to the other instruments:

1. the higher sensitivity of $Q_{\mathrm{bLS}} / Q$ to errors in the calculated average wind direction at $70 \mathrm{~m}$ downwind of the source,

2. measurement at the plume edge (Figure 8 ) and with that:

a. the higher sensitivity of $Q_{\mathrm{bLS}} / Q$ due to the smaller increase in the measured concentration above the background concentration (resulting in a higher sensitivity to the interpolation of the background concentration and to the concentration measurement itself); and

b. the higher sensitivity of $Q_{\mathrm{bLS}} / Q$ due to the smaller value of $\left\{\frac{\mathrm{C}}{Q}\right\}_{\text {sim }}$.
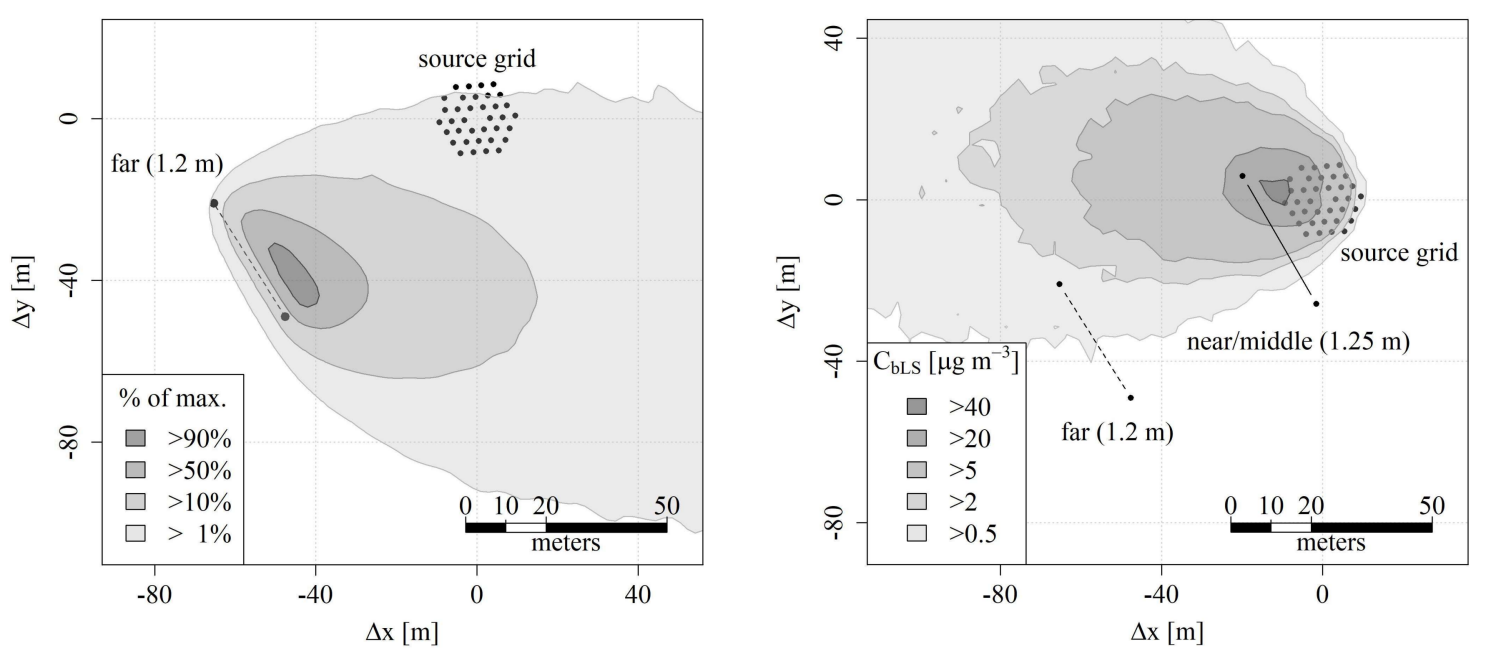

Figure 8. (Left) Modelled concentration footprint for instrument far at time $12 \mathrm{~h} 10$ to $12 \mathrm{~h} 20$. The results from this interval were excluded from the analysis for location far. The grey areas indicate the spatial distribution of the relative contribution of surface fluxes to the concentration at position far (i.e., the concentration footprint). Wind is blowing from east $\left(\beta=97^{\circ}\right)$, i.e., from right to left. (Right) Modelled concentration distribution in the horizontal plane at height $1.2 \mathrm{~m}$ a.g.l. between $12 \mathrm{~h} 10$ and $12 \mathrm{~h} 20$, assuming an emission rate identical to the source release of $6.29 \mathrm{mg} \mathrm{NH}_{3} \mathrm{~s}^{-1}$.

The latter two also introduce a higher uncertainty in the results of near/top compared to near/middle, and near/bottom, since location near/top was most of the time at the edge of the emission plume. 
In previous experiments with $\mathrm{CH}_{4}$ as a passive tracer using the same artificial source grid as in this study, we observed $Q_{\mathrm{bLS}} / Q$ values with averages of 0.96 and 1.04 under comparable conditions (see Supplement S2). While there are different possible causes for the low values of $Q_{\mathrm{bLS}} / Q$ in the present study (e.g., the parametrization of the model dispersion that is reflected i.a. by the value of $C_{0}$ ), we focus on the hypothesis that the systematically lower $Q_{\mathrm{bLS}} / Q$ values in this study are related to the dry deposition removal of $\mathrm{NH}_{3}$ between source and receptor.

\subsection{Deposition Modelling}

The canopy resistance $R_{c}$ can be modelled as the inverse of the sum of the inverse of resistances to the stomatal exchange (usually termed $R_{s}$ ) and the uptake to non-stomatal surfaces (e.g., ground surface, plant cuticle, etc.), usually termed $R_{w}$ [31]. Since the sward of the entire experimental site was treated with glyphosate one week prior to the measurements, an absence of stomatal activity can be assumed $\left(R_{S}=\infty \mathrm{s} \mathrm{m}^{-1}\right)$. Therefore, the experimentally-derived $R_{c}$ values in the context of the present study mostly describe the magnitude of $R_{w}$. Average $R_{c}^{1}$ values that explained the observed $Q_{\mathrm{bLS}} / Q$ are compatible with the $R_{w}$ parameterization by Massad et al. [32] (several hundred s $\mathrm{m}^{-1}$ at low relative humidity), and the resulting surface deposition velocities $v_{d}^{*}$ of 0.33 to $1.11 \mathrm{~cm} \mathrm{~s}^{-1}$ do not disagree with the deposition velocity ranges published in Schrader and Brümmer [15]. It needs to be mentioned that Schrader and Brümmer [15] reviewed deposition velocity values at a certain, unknown reference height above the canopy and their reported values of 0.1 to $1.8 \mathrm{~cm} \mathrm{~s}^{-1}$ (average: $0.9 \mathrm{~cm} \mathrm{~s}^{-1}$ ) for semi-natural land use would (a) increase by a certain amount if corrected down to a height of $d+z_{0}$, but also (b) decrease by a certain amount if corrected for the absence of stomatal activity.

The individual estimates of $R_{c}^{1}$ show a comparable inter-quartile range from 127 to $526 \mathrm{~s} \mathrm{~m}^{-1}$ and from 148 to $1182 \mathrm{~s} \mathrm{~m}^{-1}$ for positions near/low and near/middle and, similarly, for positions near/top and far a comparable inter-quartile range from 35 to $501 \mathrm{~s} \mathrm{~m}^{-1}$, as well as from 26 to $314 \mathrm{~s} \mathrm{~m}^{-1}$. These wide ranges reflect the turbulence-induced variability and do not indicate a physical variability of the deposition processes from one interval to the next.

Furthermore, the assumption of a constant deposition velocity over time and space can be questioned. Close to the source, the elevated deposition momentarily enhances the $\mathrm{NH}_{3}$ loading of plant and soil surfaces, which may lead to a non-zero surface equilibrium concentration. This translates physically into an increased effective surface resistance, which will induce a negative feedback on further deposition over time. Further away from the source, this surface charging-up effect is less pronounced due to a less intense exposure of the absorbing surface to $\mathrm{NH}_{3}$. As a result, the deposition velocity is expected to rise with the increasing measurement distance to the source, but the effect is not accounted for in the model.

The canopy resistance also depends on the physical and chemical conditions of the absorbing surfaces, e.g., water content, surface temperature or $\mathrm{pH}$, possibly driven by atmospheric acid gas $\left(\mathrm{SO}_{2}, \mathrm{HNO}_{3}, \mathrm{HCl}\right.$, etc. $)$ and aerosol concentrations [30]. The correlation between the recovery rate and the measured relative humidity, air temperature and $\mathrm{SO}_{2}$ concentration can be seen (Supplement $\mathrm{S} 3$ ), however, the effects are rather weak and possibly attenuate each other.

After the interruption of the gas flow through the source, the $\mathrm{NH}_{3}$ concentration did not instantaneously drop to background concentration, in contrast to the immediate response of the $\mathrm{CH}_{4}$ concentration observed in a different, comparable release experiment (data not shown). As the miniDOAS instruments measure $\mathrm{NH}_{3}, \mathrm{NO}$, and $\mathrm{SO}_{2}$ open-path, their response to the actual concentration in the air is instantaneous. Therefore, the delay in the $\mathrm{NH}_{3}$ concentration decrease is not an instrument artefact, but points towards a temporal storage of $\mathrm{NH}_{3}$ during the release phase [33]. This temporal storage is not considered by the deposition modelling where $\mathrm{NH}_{3}$ is assumed to absorb irreversibly. Therefore, the modelled values of $R_{c}$ likely represent lower bounds of $R_{c}$.

For any source that consists of small emission hot spots such as the artificial source with 36 point sources (or to be accurate, 36 tiny source areas) at ground level, the fraction of the emission that is deposited very close to the source is high. If we compare this fraction between a setup with the artificial 
source and a comparable setup with a homogeneously emitting circular source, the model shows that measurements very close to, or even above the artificial source, will be significantly different for the two model runs (Figure 9). It can then be surmised that in the case of, say, a circular slurry patch in actual field emission experiments, the fraction of dry deposited $\mathrm{NH}_{3}$ between the source and receptors with the same geometry to the total emitted $\mathrm{NH}_{3}$ would be much smaller (by a factor of more than three in the example of Figure 9). Conversely, our multiple hotspot artificial source can be compared with a cattle-grazed or sheep-grazed field, in which very significant dry deposition will occur over the unsoiled grass patches in between urine hotspots [34].

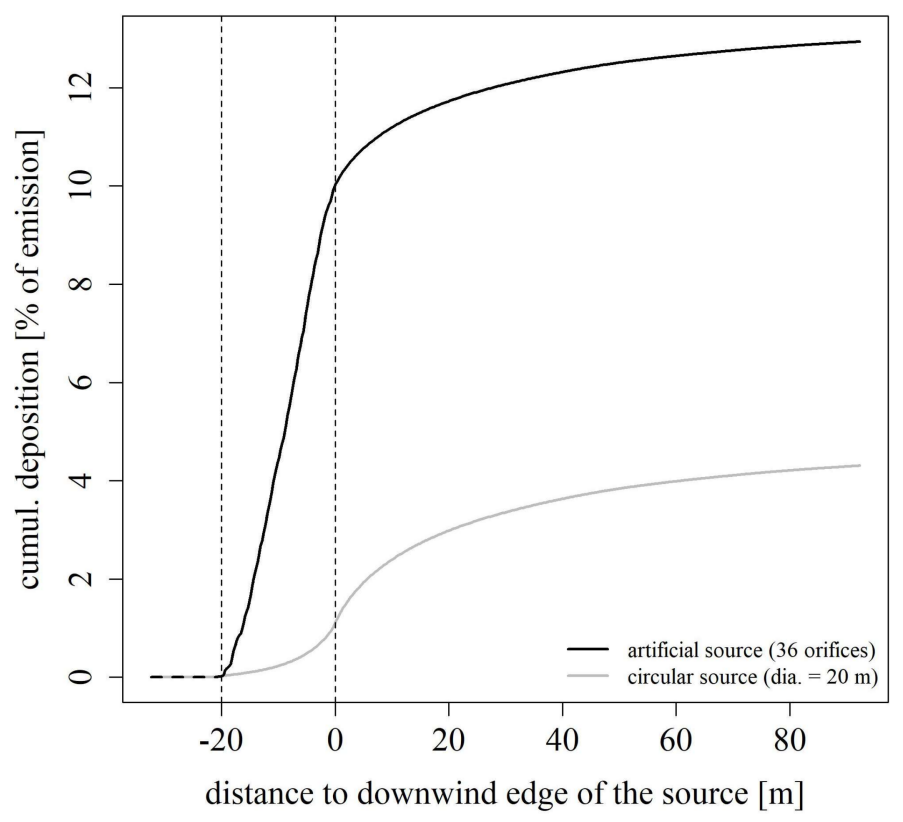

Figure 9. Modelled cumulative, cross-wind integrated fraction of emission (in \%) that is deposited up to a distance downwind of the source, in the case of a multiple-orifice artificial source versus the case of a true circular area source (e.g., homogeneous slurry patch) of the same size. The atmospheric conditions were taken from measurement interval 6 (11h30 to 11h40). A model deposition velocity $v_{d}^{*}$ of $0.35 \mathrm{~cm} \mathrm{~s}^{-1}$ was used.

Loubet et al. [35] investigated different release experiments on grassland sites and found cumulative deposition of the released $\mathrm{NH}_{3}$ within $200 \mathrm{~m}$ to be between $4 \%$ and $34 \%$. They exhibited similar findings, with largest deposition flux close to the source and a (rather) fast drop in the deposition flux with distance. These findings are consistent with the expected deposition fluxes due to the vertical mixing of the plume with time downwind of a (surface) source.

\section{Conclusions}

Micrometeorological flux measurements always produce net flux estimates. In the case of surface-interacting trace gases like $\mathrm{NH}_{3}$, a significant part can be deposited downwind of a source. For the interpretation of the flux estimates, it is, hence, important to distinguish between:

- the net emission from the footprint-related area (comprising the field of interest as well as the surrounding area);

- the net emission from confined areas (the field of interest with well-defined boundaries); and

- the net emission from hot spots within such an area (e.g., urine patches in a pasture field as investigated in Bell et al. [34]).

In the latter two cases, when emission measurements are performed downwind of confined source areas such as e.g., pasture areas or farm buildings which include livestock housings or manure stores, 
the resulting emission rates excluding dry deposition removal will underestimate the gross emissions, if the target is to evaluate emissions from the individual hot spots such as individual buildings. The estimated emission will represent the net flux from the area defined by the source area (net emission of $\mathrm{NH}_{3}$ ) plus the area between source and receptor (deposition of $\mathrm{NH}_{3}$ ). Including a dry deposition algorithm in the dispersion modelling is needed to correct for this systematic error. This applies not only for emission estimation in inverse dispersion modelling based on concentration measurements, but also for flux-footprint calculations as used in the eddy-covariance and the flux-gradient method, where the net flux from the entire footprint area is estimated from vertical flux measurements.

Furthermore, the results from this study show that for upscaling the emission from urine patch models (e.g., $[36,37])$, dry deposition inclusion is mandatory when comparing the modelled net emission from an entire pasture area to flux measurements.

The values of the dry deposition related parameters $R_{c}$ and $v_{d}^{*}$ estimated in this study are specific to the surface (i.e., canopy) conditions prevailing during the experiment (e.g., a grass canopy that has been treated with glyphosate and, thus, has no stomatal activity; low relative humidity; moderate temperatures; etc.) and, in the case of $v_{d}^{*}$, additionally on the state of the flow close to the surface (via the extent of the pseudo-laminar layer). Our recommendation for other/future inverse dispersion modelling cases is to use published models or parameterizations of $R_{c}$ available in the literature (see for example Flechard et al. [38] and references therein, in which different models are being compared). Such readily available models can be used to calculate a range of $R_{c}$ estimates from the relevant environmental variables and the range of $R_{c}$ thus obtained by different modelling approaches will provide a range of plausible estimates of the deposited $\mathrm{NH}_{3}$ between the source and receptor.

Supplementary Materials: Supplement S1 (zip): R package bLSmodelR ('bLSmodelR_4.0-1.tar.gz', 'bLSmodelR_4.0-1.zip', 'bLSmodelR-manual.pdf', 'Guide2bLSmodelR_v4.r'), processed field data ('Field Data and Geometry.xlsx', 'Field_Data.csv', 'Geometry.csv') and R script to follow the data analysis ('Data_Analysis.r'); Supplement S2 ( $p d f)$ : $\mathrm{CH}_{4}$ Release Experiment; Supplement S3 ( $\left.p d f\right)$ : Dependence of the Canopy Resistance on Environmental Parameters.

Acknowledgments: We thank Markus Jocher (Agroscope INH, Zürich, Switzerland) for technical support with the equipment on site, Bernhard Märki and Alfred Burri (Witzwil farm, Gampelen, Switzerland) for providing the experimental site and their support during the measurement period. The Swiss Federal Office for the Environment FOEN (contract 06.9115.PZ/L225-3604) and the Swiss Federal Office for Agriculture FOAG (contract 09.0084.PJ/K233-1881) are acknowledged for funding this study.

Author Contributions: C.H. designed and wrote the paper. C.F., A.N., and T.K. substantially contributed to the paper writing. C.H. wrote the bLSmodelR code and executed the dispersion modelling and deposition modelling analysis. T.K. and A.N. conceived and designed the experiment; J.S. and C.H. constructed and tested the artificial source; J.S., C.H., T.K., and A.N. performed the experiment; J.S. and C.H. processed the field data; C.F. contributed to the deposition analysis; A.N. and J.S. conceived, designed, and performed the experiment presented in Supplement S2; and J.S. processed and analyzed the data presented in Supplement S2.

Conflicts of Interest: The authors declare no conflict of interest. 


\section{Appendix A}

Table A1. Summary of the bLS input parameters, concentration averages and modelled results for each instrument location and each 10 -min interval. $u_{*}$ : friction velocity; $z_{0}$ : roughness length; $L$ : Obukhov length; $\sigma_{x} / u_{*}$ : scaled standard deviation of the along-wind $(u)$, crosswind $(v)$ and vertical $(w ;$ at Sonic height $1.25 \mathrm{~m})$ wind velocity component; $\beta$ : wind direction; $C_{0}$ : Kolmogorov coefficient; $R_{b}$ : pseudo-laminar boundary layer resistance; $\{C / Q\}_{\text {sim }}:$ modelled $C / Q$ ratio; $C_{m}$ : measured $\mathrm{NH}_{3}$ concentration; $C_{b}$ : $\mathrm{NH}_{3}$ background concentration; $Q_{\mathrm{bLS}} / Q$ : recovery rate; $R_{c}^{1}$ : canopy resistance that provided estimates of $Q_{\mathrm{bLS}} / Q$ closest to 1 (see Section 2.4.7.); $v_{d}^{*}$ : corresponding surface deposition velocity at height $z_{0}$; fetch: distance to center of the source.

\begin{tabular}{|c|c|c|c|c|c|c|c|c|c|c|c|c|c|c|c|}
\hline Interval & $\begin{array}{l}\text { Time Start } \\
(\mathrm{GMT}+1)\end{array}$ & $\begin{array}{c}u_{*} \\
\left(\mathrm{~m} \mathrm{~s}^{-1}\right)\end{array}$ & $\begin{array}{l}z_{0} \\
(\mathrm{~m})\end{array}$ & $\begin{array}{c}L \\
(\mathrm{~m})\end{array}$ & $\begin{array}{l}\frac{\sigma_{u}}{u_{*}} \\
(-)\end{array}$ & $\begin{array}{c}\sigma_{v} / u_{*} \\
(-)\end{array}$ & $\begin{array}{l}\frac{\sigma_{w w}}{u_{*}} \\
(-)\end{array}$ & $\begin{array}{l}\beta \\
\left(^{\circ}\right)\end{array}$ & $\begin{array}{l}C_{0} \\
(-)\end{array}$ & $\begin{array}{c}R_{b} \\
\left(\mathrm{~s} \mathrm{~m}^{-1}\right)\end{array}$ & $\begin{array}{l}\{C / Q\}_{\text {sim }} \\
\left(\mathrm{s} \mathrm{m}^{-1}\right)\end{array}$ & $\begin{array}{c}C_{m}-C_{b} \\
\left(\mu \mathrm{g} \mathrm{m}^{-3}\right)\end{array}$ & $\underset{(-)}{Q_{\mathrm{bLS}} / Q}$ & $\begin{array}{c}R_{c}^{1} \\
\left(\mathrm{~s} \mathrm{~m}^{-1}\right)\end{array}$ & $\begin{array}{c}v_{d}^{*} \\
\left(\mathrm{~cm} \mathrm{~s}^{-1}\right)\end{array}$ \\
\hline \multicolumn{16}{|c|}{ near/bottom, fetch: $15 \mathrm{~m}$, height: $0.5 \mathrm{~m}$ above ground level, path length (one way): $36 \mathrm{~m}$} \\
\hline nb_1 & $10 \mathrm{~h} 40$ & 0.17 & 0.004 & -2.8 & 4.2 & 5.1 & 1.70 & 68 & 4.7 & 15 & 0.00218 & 35.7 & 0.73 & 81 & 1.0 \\
\hline nb_2 & 10h50 & 0.20 & 0.003 & -4.9 & 3.9 & 3.3 & 1.42 & 67 & 4.0 & 13 & 0.00242 & 40.6 & 0.75 & 79 & 1.1 \\
\hline nb_3 & $11 \mathrm{~h} 00$ & 0.20 & 0.007 & -4.5 & 3.9 & 4.9 & 1.50 & 76 & 4.3 & 15 & 0.00213 & 43.4 & 0.92 & 399 & 0.2 \\
\hline nb_4 & $11 \mathrm{~h} 10$ & 0.22 & 0.013 & -4.2 & 3.7 & 4.4 & 1.34 & 60 & 3.6 & 16 & 0.00216 & 45.7 & 0.95 & 734 & 0.1 \\
\hline nb_5 & $11 \mathrm{~h} 20$ & 0.25 & 0.016 & -5.7 & 4.0 & 4.4 & 1.31 & 67 & 3.7 & 16 & 0.00196 & 43.1 & 0.99 & 2702 & 0.0 \\
\hline nb_6 & $11 \mathrm{~h} 30$ & 0.23 & 0.024 & -4.9 & 4.6 & 4.9 & 1.19 & 76 & 3.2 & 18 & 0.00192 & 38.1 & 0.89 & 347 & 0.3 \\
\hline nb_7 & $11 \mathrm{~h} 40$ & 0.19 & 0.005 & -2.7 & 4.3 & 3.9 & 1.60 & 73 & 4.2 & 15 & 0.00223 & 39.1 & 0.79 & 114 & 0.8 \\
\hline nb 8 & $11 \mathrm{~h} 50$ & 0.18 & 0.017 & -5.0 & 3.9 & 3.4 & 1.52 & 74 & 4.5 & 20 & 0.00244 & 49.0 & 0.90 & 357 & 0.3 \\
\hline nb_9 & $12 \mathrm{~h} 00$ & 0.22 & 0.018 & -6.2 & 3.1 & 4.0 & 1.25 & 103 & 3.5 & 18 & 0.00154 & 26.9 & 0.79 & 101 & 0.8 \\
\hline nb 10 & $12 \mathrm{~h} 10$ & 0.17 & 0.002 & -1.9 & 4.2 & 5.5 & 1.90 & 97 & 5.0 & 13 & 0.00151 & 39.3 & 1.17 & $\infty$ & 0.0 \\
\hline nb_11 & $12 \mathrm{~h} 20$ & 0.16 & 0.004 & -1.3 & 4.6 & 6.9 & 1.86 & 82 & 4.1 & 15 & 0.00176 & 39.7 & 1.02 & $\infty$ & 0.0 \\
\hline nb 12 & $12 \mathrm{~h} 30$ & 0.20 & 0.010 & -2.7 & 4.5 & 4.4 & 1.51 & 60 & 3.8 & 17 & 0.00202 & 37.2 & 0.83 & 166 & 0.5 \\
\hline nb_13 & $12 \mathrm{~h} 40$ & 0.17 & 0.008 & -1.8 & 4.1 & 6.8 & 1.63 & 86 & 3.7 & 18 & 0.00173 & 34.0 & 0.88 & 320 & 0.3 \\
\hline nb 14 & $12 \mathrm{~h} 50$ & 0.24 & 0.021 & -6.1 & 3.4 & 3.2 & 1.15 & 45 & 3.2 & 17 & 0.00250 & 46.5 & 0.84 & 167 & 0.5 \\
\hline nb_15 & $13 \mathrm{~h} 00$ & 0.23 & 0.006 & -4.1 & 3.4 & 3.0 & 1.32 & 58 & 3.5 & 13 & 0.00236 & 48.5 & 0.92 & 425 & 0.2 \\
\hline nb 16 & $13 \mathrm{~h} 10$ & 0.16 & 0.002 & -1.7 & 4.8 & 5.1 & 1.63 & 73 & 3.7 & 14 & 0.00245 & 40.3 & 0.74 & 107 & 0.8 \\
\hline nb_17 & $13 \mathrm{~h} 20$ & 0.22 & 0.011 & -3.6 & 4.1 & 4.1 & 1.48 & 94 & 4.0 & 16 & 0.00157 & 30.3 & 0.87 & 207 & 0.4 \\
\hline nb_18 & $13 \mathrm{~h} 30$ & 0.26 & 0.015 & -7.1 & 3.8 & 3.5 & 1.16 & 65 & 3.2 & 15 & 0.00228 & 47.6 & 0.94 & 560 & 0.2 \\
\hline
\end{tabular}


Table A1. Cont.

\begin{tabular}{|c|c|c|c|c|c|c|c|c|c|c|c|c|c|c|c|}
\hline Interval & $\begin{array}{l}\text { Time Start } \\
(\text { GMT + 1) }\end{array}$ & $\begin{array}{c}u_{*} \\
\left(\mathrm{~m} \mathrm{~s}^{-1}\right)\end{array}$ & $\begin{array}{l}z_{0} \\
(\mathrm{~m})\end{array}$ & $\begin{array}{c}L \\
(\mathrm{~m})\end{array}$ & $\begin{array}{l}\frac{\sigma_{u}}{u_{*}} \\
(-)\end{array}$ & $\begin{array}{c}\sigma_{v} / u_{*} \\
(-)\end{array}$ & $\begin{array}{l}\frac{\sigma_{w w}}{u_{*}} \\
(-)\end{array}$ & $\begin{array}{l}\beta \\
\left(^{\circ}\right)\end{array}$ & $\begin{array}{l}C_{0} \\
(-)\end{array}$ & $\begin{array}{c}R_{b} \\
\left(\mathrm{~s} \mathrm{~m}^{-1}\right)\end{array}$ & $\begin{array}{l}\{C / Q\}_{\text {sim }} \\
\left(\mathrm{s} \mathrm{m}^{-1}\right)\end{array}$ & $\begin{array}{c}C_{m}-C_{b} \\
\left(\mu \mathrm{g} \mathrm{m}^{-3}\right)\end{array}$ & $\underset{(-)}{Q_{\mathrm{bLS}} / Q}$ & $\begin{array}{c}R_{c}^{1} \\
\left(\mathrm{~s} \mathrm{~m}^{-1}\right)\end{array}$ & $\begin{array}{c}v_{d}^{*} \\
\left(\mathrm{~cm} \mathrm{~s}^{-1}\right)\end{array}$ \\
\hline \multicolumn{16}{|c|}{ near/middle, fetch: 15 m, height: 1.25 m above ground level, path length (one way): $36 \mathrm{~m}$} \\
\hline nm_1 & $10 \mathrm{~h} 40$ & 0.17 & 0.004 & -2.8 & 4.2 & 5.1 & 1.70 & 68 & 4.7 & 15 & 0.00124 & 20.7 & 0.75 & 63 & 1.3 \\
\hline nm_2 & 10h50 & 0.20 & 0.003 & -4.9 & 3.9 & 3.3 & 1.42 & 67 & 4.0 & 13 & 0.00108 & 20.3 & 0.84 & 124 & 0.7 \\
\hline nm_3 & $11 \mathrm{~h} 00$ & 0.20 & 0.007 & -4.5 & 3.9 & 4.9 & 1.50 & 76 & 4.3 & 15 & 0.00110 & 23.8 & 0.98 & 1268 & 0.1 \\
\hline nm_4 & $11 \mathrm{~h} 10$ & 0.22 & 0.013 & -4.2 & 3.7 & 4.4 & 1.34 & 60 & 3.6 & 16 & 0.00132 & 26.2 & 0.90 & 239 & 0.4 \\
\hline nm_5 & $11 \mathrm{~h} 20$ & 0.25 & 0.016 & -5.7 & 4.0 & 4.4 & 1.31 & 67 & 3.7 & 16 & 0.00112 & 25.5 & 1.02 & $\infty$ & 0.0 \\
\hline nm_6 & $11 \mathrm{~h} 30$ & 0.23 & 0.024 & -4.9 & 4.6 & 4.9 & 1.19 & 76 & 3.2 & 18 & 0.00110 & 23.6 & 0.96 & 925 & 0.1 \\
\hline nm_7 & $11 \mathrm{~h} 40$ & 0.19 & 0.005 & -2.7 & 4.3 & 3.9 & 1.60 & 73 & 4.2 & 15 & 0.00120 & 22.7 & 0.85 & 161 & 0.6 \\
\hline nm_8 & $11 \mathrm{~h} 50$ & 0.18 & 0.017 & -5.0 & 3.9 & 3.4 & 1.52 & 74 & 4.5 & 20 & 0.00155 & 27.2 & 0.79 & 80 & 1.0 \\
\hline nm_9 & $12 \mathrm{~h} 00$ & 0.22 & 0.018 & -6.2 & 3.1 & 4.0 & 1.25 & 103 & 3.5 & 18 & 0.00098 & 15.4 & 0.70 & 38 & 1.8 \\
\hline nm_10 & $12 \mathrm{~h} 10$ & 0.17 & 0.002 & -1.9 & 4.2 & 5.5 & 1.90 & 97 & 5.0 & 13 & 0.00084 & 22.7 & 1.21 & $\infty$ & 0.0 \\
\hline nm_11 & $12 \mathrm{~h} 20$ & 0.16 & 0.004 & -1.3 & 4.6 & 6.9 & 1.86 & 82 & 4.1 & 15 & 0.00103 & 22.9 & 1.00 & 9126 & 0.0 \\
\hline nm_12 & $12 \mathrm{~h} 30$ & 0.20 & 0.010 & -2.7 & 4.5 & 4.4 & 1.51 & 60 & 3.8 & 17 & 0.00119 & 22.2 & 0.84 & 150 & 0.6 \\
\hline nm_13 & $12 \mathrm{~h} 40$ & 0.17 & 0.008 & -1.8 & 4.1 & 6.8 & 1.63 & 86 & 3.7 & 18 & 0.00103 & 21.9 & 0.96 & 881 & 0.1 \\
\hline nm_14 & $12 \mathrm{~h} 50$ & 0.24 & 0.021 & -6.1 & 3.4 & 3.2 & 1.15 & 45 & 3.2 & 17 & 0.00145 & 27.8 & 0.87 & 172 & 0.5 \\
\hline nm_15 & $13 \mathrm{~h} 00$ & 0.23 & 0.006 & -4.1 & 3.4 & 3.0 & 1.32 & 58 & 3.5 & 13 & 0.00112 & 25.9 & 1.04 & $\infty$ & 0.0 \\
\hline nm_16 & $13 \mathrm{~h} 10$ & 0.16 & 0.002 & -1.7 & 4.8 & 5.1 & 1.63 & 73 & 3.7 & 14 & 0.00120 & 22.5 & 0.84 & 206 & 0.5 \\
\hline nm_17 & $13 \mathrm{~h} 20$ & 0.22 & 0.011 & -3.6 & 4.1 & 4.1 & 1.48 & 94 & 4.0 & 16 & 0.00096 & 19.5 & 0.92 & 274 & 0.3 \\
\hline nm_18 & $13 \mathrm{~h} 30$ & 0.26 & 0.015 & -7.1 & 3.8 & 3.5 & 1.16 & 65 & 3.2 & 15 & 0.00124 & 23.4 & 0.85 & 147 & 0.6 \\
\hline
\end{tabular}


Table A1. Cont.

\begin{tabular}{|c|c|c|c|c|c|c|c|c|c|c|c|c|c|c|c|}
\hline Interval & $\begin{array}{l}\text { Time Start } \\
(\text { GMT + 1) }\end{array}$ & $\begin{array}{c}u_{*} \\
\left(\mathrm{~m} \mathrm{~s}^{-1}\right)\end{array}$ & $\begin{array}{l}z_{0} \\
(\mathrm{~m})\end{array}$ & $\begin{array}{c}L \\
(\mathrm{~m})\end{array}$ & $\begin{array}{l}\frac{\sigma_{u}}{u_{*}} \\
(-)\end{array}$ & $\begin{array}{c}\sigma_{v} / u_{*} \\
(-)\end{array}$ & $\begin{array}{l}\frac{\sigma_{w v}}{u_{*}} \\
(-)\end{array}$ & $\begin{array}{l}\beta \\
\left(^{\circ}\right)\end{array}$ & $\begin{array}{l}C_{0} \\
(-)\end{array}$ & $\begin{array}{c}R_{b} \\
\left(\mathrm{~s} \mathrm{~m}^{-1}\right)\end{array}$ & $\begin{array}{l}\{C / Q\}_{\text {sim }} \\
\left(\mathrm{s} \mathrm{m}^{-1}\right)\end{array}$ & $\begin{array}{c}C_{m}-C_{b} \\
\left(\mu \mathrm{g} \mathrm{m}^{-3}\right)\end{array}$ & $\underset{(-)}{Q_{\mathrm{bLS}} / Q}$ & $\begin{array}{c}R_{c}^{1} \\
\left(\mathrm{~s} \mathrm{~m}^{-1}\right)\end{array}$ & $\begin{array}{c}v_{d}^{*} \\
\left(\mathrm{~cm} \mathrm{~s}^{-1}\right)\end{array}$ \\
\hline \multicolumn{16}{|c|}{ near/top, fetch: $15 \mathrm{~m}$, height: $3.0 \mathrm{~m}$ above ground level, path length (one way): $37 \mathrm{~m}$} \\
\hline nt_1 & $10 \mathrm{~h} 40$ & 0.17 & 0.004 & -2.8 & 4.2 & 5.1 & 1.70 & 68 & 4.7 & 15 & 0.00033 & 4.9 & 0.66 & 30 & 2.2 \\
\hline nt_2 & $10 \mathrm{~h} 50$ & 0.20 & 0.003 & -4.9 & 3.9 & 3.3 & 1.42 & 67 & 4.0 & 13 & 0.00021 & 3.4 & 0.73 & 35 & 2.1 \\
\hline nt_3 & $11 \mathrm{~h} 00$ & 0.20 & 0.007 & -4.5 & 3.9 & 4.9 & 1.50 & 76 & 4.3 & 15 & 0.00026 & 5.2 & 0.88 & 149 & 0.6 \\
\hline nt_4 & $11 \mathrm{~h} 10$ & 0.22 & 0.013 & -4.2 & 3.7 & 4.4 & 1.34 & 60 & 3.6 & 16 & 0.00038 & 6.4 & 0.75 & 63 & 1.3 \\
\hline nt_5 & $11 \mathrm{~h} 20$ & 0.25 & 0.016 & -5.7 & 4.0 & 4.4 & 1.31 & 67 & 3.7 & 16 & 0.00031 & 7.7 & 1.10 & $\infty$ & 0.0 \\
\hline nt_6 & $11 \mathrm{~h} 30$ & 0.23 & 0.024 & -4.9 & 4.6 & 4.9 & 1.19 & 76 & 3.2 & 18 & 0.00034 & 6.9 & 0.91 & 338 & 0.3 \\
\hline nt_7 & $11 \mathrm{~h} 40$ & 0.19 & 0.005 & -2.7 & 4.3 & 3.9 & 1.60 & 73 & 4.2 & 15 & 0.00035 & 5.8 & 0.74 & 51 & 1.5 \\
\hline nt_8 & $11 \mathrm{~h} 50$ & 0.18 & 0.017 & -5.0 & 3.9 & 3.4 & 1.52 & 74 & 4.5 & 20 & 0.00052 & 6.2 & 0.54 & 0 & 4.9 \\
\hline nt_9 & $12 \mathrm{~h} 00$ & 0.22 & 0.018 & -6.2 & 3.1 & 4.0 & 1.25 & 103 & 3.5 & 18 & 0.00025 & 2.6 & 0.46 & 0 & 5.7 \\
\hline nt_10 & $12 \mathrm{~h} 10$ & 0.17 & 0.002 & -1.9 & 4.2 & 5.5 & 1.90 & 97 & 5.0 & 13 & 0.00023 & 5.4 & 1.04 & $\infty$ & 0.0 \\
\hline nt_11 & $12 \mathrm{~h} 20$ & 0.16 & 0.004 & -1.3 & 4.6 & 6.9 & 1.86 & 82 & 4.1 & 15 & 0.00034 & 7.0 & 0.93 & 555 & 0.2 \\
\hline nt_12 & $12 \mathrm{~h} 30$ & 0.20 & 0.010 & -2.7 & 4.5 & 4.4 & 1.51 & 60 & 3.8 & 17 & 0.00041 & 8.4 & 0.91 & 275 & 0.3 \\
\hline nt_13 & $12 \mathrm{~h} 40$ & 0.17 & 0.008 & -1.8 & 4.1 & 6.8 & 1.63 & 86 & 3.7 & 18 & 0.00033 & 7.7 & 1.06 & $\infty$ & 0.0 \\
\hline nt_14 & $12 \mathrm{~h} 50$ & 0.24 & 0.021 & -6.1 & 3.4 & 3.2 & 1.15 & 45 & 3.2 & 17 & 0.00043 & 8.1 & 0.84 & 118 & 0.7 \\
\hline nt_15 & $13 \mathrm{~h} 00$ & 0.23 & 0.006 & -4.1 & 3.4 & 3.0 & 1.32 & 58 & 3.5 & 13 & 0.00024 & 6.2 & 1.15 & $\infty$ & 0.0 \\
\hline nt_16 & $13 \mathrm{~h} 10$ & 0.16 & 0.002 & -1.7 & 4.8 & 5.1 & 1.63 & 73 & 3.7 & 14 & 0.00035 & 6.8 & 0.88 & 283 & 0.3 \\
\hline nt_17 & $13 \mathrm{~h} 20$ & 0.22 & 0.011 & -3.6 & 4.1 & 4.1 & 1.48 & 94 & 4.0 & 16 & 0.00031 & 5.0 & 0.72 & 35 & 2.0 \\
\hline nt_18 & $13 \mathrm{~h} 30$ & 0.26 & 0.015 & -7.1 & 3.8 & 3.5 & 1.16 & 65 & 3.2 & 15 & 0.00029 & 4.6 & 0.70 & 32 & 2.1 \\
\hline
\end{tabular}


Table A1. Cont.

\begin{tabular}{|c|c|c|c|c|c|c|c|c|c|c|c|c|c|c|c|}
\hline Interval & $\begin{array}{l}\text { Time Start } \\
(\mathrm{GMT}+1) \\
\end{array}$ & $\begin{array}{c}u_{*} \\
\left(\mathrm{~m} \mathrm{~s}^{-1}\right) \\
\end{array}$ & $\begin{array}{c}z_{0} \\
(\mathrm{~m})\end{array}$ & $\begin{array}{c}L \\
(\mathrm{~m}) \\
\end{array}$ & $\begin{array}{l}\frac{\sigma_{u}}{u_{*}} \\
(-)\end{array}$ & $\begin{array}{c}\sigma_{v} / u_{*} \\
(-)\end{array}$ & $\begin{array}{l}\frac{\sigma_{w}}{u_{*}} \\
(-)\end{array}$ & $\begin{array}{c}\beta \\
\left({ }^{\circ}\right) \\
\end{array}$ & $\begin{array}{l}C_{0} \\
(-) \\
\end{array}$ & $\begin{array}{c}R_{b} \\
\left(\mathrm{~s} \mathrm{~m}^{-1}\right) \\
\end{array}$ & $\begin{array}{l}\{C / Q\}_{\text {sim }} \\
\left(\mathrm{s} \mathrm{m}^{-1}\right)\end{array}$ & 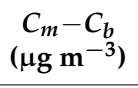 & $\underset{(-)}{Q_{\mathrm{bLS}} / Q}$ & $\begin{array}{c}R_{c}^{1} \\
\left(\mathrm{~s} \mathrm{~m}^{-1}\right) \\
\end{array}$ & $\begin{array}{c}v_{d}^{*} \\
\left(\mathrm{~cm} \mathrm{~s}^{-1}\right)\end{array}$ \\
\hline \multicolumn{16}{|c|}{ far, fetch: $70 \mathrm{~m}$, height: $1.2 \mathrm{~m}$ above ground level, path length (one way): $33 \mathrm{~m}$} \\
\hline f_1 & $10 \mathrm{~h} 40$ & 0.17 & 0.004 & -2.8 & 4.2 & 5.1 & 1.70 & 68 & 4.7 & 15 & 0.00020 & 2.8 & 0.64 & 56 & 1.4 \\
\hline f_2 & $10 \mathrm{~h} 50$ & 0.20 & 0.003 & -4.9 & 3.9 & 3.3 & 1.42 & 67 & 4.0 & 13 & 0.00033 & 3.7 & 0.51 & 17 & 3.3 \\
\hline f_3 & $11 \mathrm{~h} 00$ & 0.20 & 0.007 & -4.5 & 3.9 & 4.9 & 1.50 & 76 & 4.3 & 15 & 0.00018 & 3.7 & 0.93 & 548 & 0.2 \\
\hline f_4 & $11 \mathrm{~h} 10$ & 0.22 & 0.013 & -4.2 & 3.7 & 4.4 & 1.34 & 60 & 3.6 & 16 & 0.00021 & 2.5 & 0.54 & 31 & 2.1 \\
\hline f_5 & $11 \mathrm{~h} 20$ & 0.25 & 0.016 & -5.7 & 4.0 & 4.4 & 1.31 & 67 & 3.7 & 16 & 0.00019 & 3.3 & 0.77 & 121 & 0.7 \\
\hline f_6 & $11 \mathrm{~h} 30$ & 0.23 & 0.024 & -4.9 & 4.6 & 4.9 & 1.19 & 76 & 3.2 & 18 & 0.00015 & 2.3 & 0.72 & 109 & 0.8 \\
\hline f_7 & $11 \mathrm{~h} 40$ & 0.19 & 0.005 & -2.7 & 4.3 & 3.9 & 1.60 & 73 & 4.2 & 15 & 0.00017 & 2.1 & 0.56 & 26 & 2.5 \\
\hline f_8 & $11 \mathrm{~h} 50$ & 0.18 & 0.017 & -5.0 & 3.9 & 3.4 & 1.52 & 74 & 4.5 & 20 & 0.00020 & 2.5 & 0.57 & 22 & 2.4 \\
\hline f_9 & $12 \mathrm{~h} 00$ & 0.22 & 0.018 & -6.2 & 3.1 & 4.0 & 1.25 & 103 & 3.5 & 18 & 0.00003 & 0.6 & 0.94 & 314 & 0.3 \\
\hline$f_{-} 10^{1}$ & $12 \mathrm{~h} 10$ & 0.17 & 0.002 & -1.9 & 4.2 & 5.5 & 1.90 & 97 & 5.0 & 13 & 0.00003 & 2.6 & $4.37^{1}$ & $\infty^{1}$ & $0.0^{1}$ \\
\hline f_11 & $12 \mathrm{~h} 20$ & 0.16 & 0.004 & -1.3 & 4.6 & 6.9 & 1.86 & 82 & 4.1 & 15 & 0.00009 & 2.1 & 1.05 & $\infty$ & 0.0 \\
\hline f_12 & $12 \mathrm{~h} 30$ & 0.20 & 0.010 & -2.7 & 4.5 & 4.4 & 1.51 & 60 & 3.8 & 17 & 0.00019 & 2.8 & 0.67 & 78 & 1.1 \\
\hline f_13 & $12 \mathrm{~h} 40$ & 0.17 & 0.008 & -1.8 & 4.1 & 6.8 & 1.63 & 86 & 3.7 & 18 & 0.00009 & 1.8 & 0.87 & 318 & 0.3 \\
\hline f_14 & $12 \mathrm{~h} 50$ & 0.24 & 0.021 & -6.1 & 3.4 & 3.2 & 1.15 & 45 & 3.2 & 17 & 0.00023 & 2.2 & 0.44 & 6 & 4.3 \\
\hline f_15 & $13 \mathrm{~h} 00$ & 0.23 & 0.006 & -4.1 & 3.4 & 3.0 & 1.32 & 58 & 3.5 & 13 & 0.00039 & 3.4 & 0.39 & 0 & 7.2 \\
\hline f_-16 & $13 \mathrm{~h} 10$ & 0.16 & 0.002 & -1.7 & 4.8 & 5.1 & 1.63 & 73 & 3.7 & 14 & 0.00017 & 2.7 & 0.71 & 114 & 0.8 \\
\hline f_17 & $13 \mathrm{~h} 20$ & 0.22 & 0.011 & -3.6 & 4.1 & 4.1 & 1.48 & 94 & 4.0 & 16 & 0.00004 & 0.9 & 0.93 & 380 & 0.3 \\
\hline f_18 & $13 \mathrm{~h} 30$ & 0.26 & 0.015 & -7.1 & 3.8 & 3.5 & 1.16 & 65 & 3.2 & 15 & 0.00029 & 3.5 & 0.54 & 30 & 2.2 \\
\hline
\end{tabular}

${ }^{1}$ interval f 10 was removed from the analysis. 


\section{References}

1. Coates, T.W.; Flesch, T.K.; McGinn, S.M.; Charmley, E.; Chen, D. Evaluating an eddy covariance technique to estimate point-source emissions and its potential application to grazing cattle. Agric. For. Meteorol. 2017, 234-235, 164-171. [CrossRef]

2. Felber, R.; Münger, A.; Neftel, A.; Ammann, C. Eddy covariance methane flux measurements over a grazed pasture: Effect of cows as moving point sources. Biogeosciences 2015, 12, 3419-3468. [CrossRef]

3. Laubach, J.; Kelliher, F.M.; Knight, T.W.; Clark, H.; Molano, G.; Cavanagh, A. Methane emissions from beef cattle-A comparison of paddock- and animal-scale measurements. Aust. J. Exp. Agric. 2008, 48, 132-137. [CrossRef]

4. Laubach, J.; Taghizadeh-Toosi, A.; Sherlock, R.R.; Kelliher, F.M. Measuring and modelling ammonia emissions from a regular pattern of cattle urine patches. Agric. For. Meteorol. 2012, 156, 1-17. [CrossRef]

5. Loubet, B.; Génermont, S.; Ferrara, R.M.; Bedos, C.; Decuq, C.; Personne, E.; Fanucci, O.; Durand, B.; Rana, G.; Cellier, P. An inverse model to estimate ammonia emissions from fields. Eur. J. Soil Sci. 2010, 61, 793-805. [CrossRef]

6. Sintermann, J.; Ammann, C.; Kuhn, U.; Spirig, C.; Hirschberger, R.; Gartner, A.; Neftel, A. Determination of field scale ammonia emissions for common slurry spreading practice with two independent methods. Atmos. Meas. Tech. 2011, 4, 1821-1840. [CrossRef]

7. Wilson, J.D.; Flesch, T.K.; Crenna, B.P. Estimating Surface-Air Gas Fluxes by Inverse Dispersion Using a Backward Lagrangian Stochastic Trajectory Model. In Lagrangian Modeling of the Atmosphere; Lin, J., Brunner, D., Gerbig, C., Stohl, A., Luhar, A., Webley, P., Eds.; American Geophysical Union: Washington, DC, USA, 2012; pp. 149-162.

8. Flesch, T.K.; Wilson, J.D.; Harper, L.A.; Crenna, B.P.; Sharpe, R.R. Deducing ground-to-air emissions from observed trace gas concentrations: A field trial. J. Appl. Meteorol. 2004, 43, 487-502. [CrossRef]

9. Carozzi, M.; Loubet, B.; Acutis, M.; Rana, G.; Ferrara, R.M. Inverse dispersion modelling highlights the efficiency of slurry injection to reduce ammonia losses by agriculture in the Po Valley (Italy). Agric. For. Meteorol. 2013, 171, 306-318. [CrossRef]

10. Flesch, T.K.; Harper, L.A.; Powell, J.M.; Wilson, J.D. Inverse-dispersion calculation of ammonia emissions from Wisconsin dairy farms. Trans. ASABE 2009, 52, 253-265. [CrossRef]

11. Grant, R.H.; Boehm, M.T.; Bogan, B.W. Methane and carbon dioxide emissions from manure storage facilities at two free-stall dairies. Agric. For. Meteorol. 2015, 213, 102-113. [CrossRef]

12. Harper, L.A.; Flesch, T.K.; Weaver, K.H.; Wilson, J.D. The effect of biofuel production on swine farm methane and ammonia emissions. J. Environ. Qual. 2010, 39, 1984-1992. [CrossRef] [PubMed]

13. McGinn, S.M.; Flesch, T.K.; Crenna, B.P.; Beauchemin, K.A.; Coates, T. Quantifying ammonia emissions from a cattle feedlot using a dispersion model. J. Environ. Qual. 2007, 36, 1585-1590. [CrossRef] [PubMed]

14. Flechard, C.R. Turbulent Exchange of Ammonia above Vegetation (BL). Ph.D. Thesis, University of Nottingham, Nottingham, UK, 1998.

15. Schrader, F.; Brümmer, C. Land use specific ammonia deposition velocities: A review of recent studies (2004-2013). Water Air Soil Pollut. 2014, 225, 2114. [CrossRef] [PubMed]

16. Asman, W.A.H.; Sutton, M.A.; Schjørring, J.K. Ammonia: Emission, atmospheric transport and deposition. New Phytol. 1998, 139, 27-48. [CrossRef]

17. Loubet, B.; Asman, W.A.H.; Theobald, M.R.; Hertel, O.; Tang, Y.S.; Robin, P.; Hassouna, M.; Dämmgen, U.; Genermont, S.; Cellier, P.; et al. Ammonia Deposition Near Hot Spots: Processes, Models and Monitoring Methods. In Atmospheric Ammonia; Sutton, M.A., Reis, S., Baker, S.M.H., Eds.; Springer: Dordrecht, The Netherlands, 2009; pp. 205-267.

18. R Core Team. R: A language and environment for statistical computing; R Foundation for Statistical Computing: Vienna, Austria, 2018.

19. Flesch, T.K.; Wilson, J.D.; Yee, E. Backward-time Lagrangian stochastic dispersion models and their application to estimate gaseous Emissions. J. Appl. Meteorol. 1995, 34, 1320-1332. [CrossRef]

20. Wilson, J.D.; Ferrandino, F.J.; Thurtell, G.W. A relationship between deposition velocity and trajectory reflection probability for use in stochastic Lagrangian dispersion models. Agric. For. Meteorol. 1989, 47, 139-154. [CrossRef] 
21. Knaus, J. snowfall: Easier Cluster Computing (Based on snow). R Package Version 1.84-6.1. Available online: https: / CRAN.R-project.org/package=snowfall (accessed on 1 January 2017).

22. Luke, T.; Rossini, A.J.; Li, N.; Sevcikova, H. snow: Simple Network of Workstations. R Package Version 0.4-2. Available online: https: / CRAN.R-project.org/package=snow (accessed on 1 January 2017).

23. Eddelbuettel, D.; François, R. Rcpp: Seamless R and C++ Integration. J. Stat. Softw. 2011, 40, 1-18. [CrossRef]

24. Dowle, M.; Srinivasan, A. data.table: Extension of 'data.frame'. R Package Version 1.10.4. Available online: https: / /CRAN.R-project.org/package=data.table (accessed on 1 January 2018).

25. Sintermann, J.; Dietrich, K.; Häni, C.; Bell, M.; Jocher, M.; Neftel, A. A miniDOAS instrument optimised for ammonia field measurements. Atmos. Meas. Tech. 2016, 9, 2721-2734. [CrossRef]

26. Sutton, M.A.; Schjorring, J.K.; Wyers, G.P.; Duyzer, J.H.; Ineson, P.; Powlson, D.S. Plant-atmosphere exchange of ammonia [and discussion]. Philos. Trans. R. Soc. A 1995, 351, 261-278. [CrossRef]

27. Garland, J.A. The dry deposition of sulphur dioxide to land and water surfaces. Proc. R. Soc. A 1977, 354, 245-268. [CrossRef]

28. Cussler, E.L. Diffusion: Mass Transfer in Fluid Systems, 3rd ed.; 6th printing; Cambridge University Press: Cambridge, UK, 2013.

29. Tang, M.J.; Cox, R.A.; Kalberer, M. Compilation and evaluation of gas phase diffusion coefficients of reactive trace gases in the atmosphere: Volume 1. Inorganic compounds. Atmos. Chem. Phys. 2014, 14, 9233-9247. [CrossRef]

30. Flechard, C.R.; Massad, R.S.; Loubet, B.; Personne, E.; Simpson, D.; Bash, J.O.; Cooter, E.J.; Nemitz, E.; Sutton, M.A. Advances in understanding, models and parameterizations of biosphere-atmosphere ammonia exchange. Biogeosciences 2013, 10, 5183-5225. [CrossRef]

31. Flechard, C.R.; Spirig, C.; Neftel, A.; Ammann, C. The annual ammonia budget of fertilised cut grassland-Part 2: Seasonal variations and compensation point modeling. Biogeosciences 2010, 7, 537-556. [CrossRef]

32. Massad, R.S.; Nemitz, E.; Sutton, M.A. Review and parameterisation of bi-directional ammonia exchange between vegetation and the atmosphere. Atmos. Chem. Phys. 2010, 10, 10359-10386. [CrossRef]

33. Sutton, M.A.; Burkhardt, J.K.; Guerin, D.; Nemitz, E.; Fowler, D. Development of resistance models to describe measurements of bi-directional ammonia surface-atmosphere exchange. Atmos. Environ. 1998, 32, 473-480. [CrossRef]

34. Bell, M.; Flechard, C.; Fauvel, Y.; Häni, C.; Sintermann, J.; Jocher, M.; Menzi, H.; Hensen, A.; Neftel, A. Ammonia emissions from a grazed field estimated by miniDOAS measurements and inverse dispersion modelling. Atmos. Meas. Tech. 2017, 10, 1875-1892. [CrossRef]

35. Loubet, B.; Cellier, P.; Milford, C.; Sutton, M.A. A coupled dispersion and exchange model for short-range dry deposition of atmospheric ammonia. Q. J. R. Meteorol. Soc. 2006, 132, 1733-1763. [CrossRef]

36. Giltrap, D.; Saggar, S.; Rodriguez, J.; Bishop, P. Modelling $\mathrm{NH}_{3}$ volatilisation within a urine patch using NZ-DNDC. Nutr. Cycl. Agroecosyst. 2017, 108, 267-277. [CrossRef]

37. Móring, A.; Vieno, M.; Doherty, R.M.; Milford, C.; Nemitz, E.; Twigg, M.M.; Horváth, L.; Sutton, M.A. Process-based modelling of $\mathrm{NH}_{3}$ exchange with grazed grasslands. Biogeosciences 2017, 14, 4161-4193. [CrossRef]

38. Flechard, C.R.; Nemitz, E.; Smith, R.I.; Fowler, D.; Vermeulen, A.T.; Bleeker, A.; Erisman, J.W.; Simpson, D.; Zhang, L.; Tang, Y.S.; et al. Dry deposition of reactive nitrogen to European ecosystems: A comparison of inferential models across the NitroEurope network. Atmos. Chem. Phys. 2011, 11, 2703-2728. [CrossRef]

(C) 2018 by the authors. Licensee MDPI, Basel, Switzerland. This article is an open access article distributed under the terms and conditions of the Creative Commons Attribution (CC BY) license (http://creativecommons.org/licenses/by/4.0/). 